\title{
Molecular cloning, pharmacological characterization, and histochemical distribution of frog vasotocin and mesotocin receptors
}

\author{
S Acharjee, J-L Do-Rego', D Y Oh, J S Moon, R S Ahn, K Lee, D G Bai, H Vaudry', \\ H B Kwon and J Y Seong \\ Hormone Research Center, School of Biological Sciences and Technology, Chonnam National University, Gwangju 500-757, Korea \\ ${ }^{1}$ European Institute for Peptide Research (IFRMP 23), Laboratory of Cellular and Molecular Neuroendocrinology, INSERM U413, University of Rouen, \\ 76821 Mont-Saint-Aignan, France
}

(Requests for offprints should be addressed to J Y Seong; Email: jyseong @chonnam.ac.kr)

\begin{abstract}
The neurohypophysial nonapeptides vasotocin (VT) and mesotocin (MT) are the amphibian counterparts of arginine vasopressin (AVP) and oxytocin (OT). We have here reported the cloning and functional characterization of the receptors for vasotocin (VTR) and mesotocin (MTR) in two species of frog, Rana catesbeiana and Rana esculenta. The frog VTR and MTR cDNAs encode proteins of 419 and 384 amino acids respectively. Frog VTR exhibits a high degree of sequence identity with the mammalian AVP-1a (V1a) receptor while the frog MTR possesses a high degree of sequence identity with the mammalian OT receptor. Activation of VTR induced both c-fos promoter- and cAMP-responsive element (CRE)-driven transcriptional activities, while activation of MTR induced c-fos promoter-driven transcriptional activity but failed to evoke CRE-driven transcriptional activity, suggesting differential G protein coupling between VTR and MTR. The VTR exhibited the highest sensitivity for VT followed by OT $>A V P \approx M T$, whereas the MTR showed preferential ligand sensitivity for MT > OT > VT > AVP. A V1a agonist but not V2 and OT agonists substantially activated both VTR and MTR with a similar sensitivity. V1a, V2 and OT antagonists inhibited MT-induced MTR activation but not VT-induced VTR activation. In the frog brain, VTR and MTR mRNAs were found to be widely expressed in the telencephalon, diencephalon and mesencephalon, and exhibited very similar regional distribution. In the pituitary, VTR and MTR were expressed in the distal and intermediate lobes but were virtually absent in the neural lobe. Taken together, these data indicated that, although the distribution of VTR and MTR largely overlaps in the frog brain and pituitary, VT and MT may play distinct activities owing to the ligand selectivity and different signaling pathways activated by their receptors.
\end{abstract}

Journal of Molecular Endocrinology (2004) 33, 293-313

\section{Introduction}

In mammals, the neurohypophysial hormones arginine vasopressin (AVP) and oxytocin (OT) exhibit a wide range of biological activities both as neurohormones secreted in the posterior pituitary and neuromediators released in the central nervous system. At the periphery, AVP regulates water excretion, vascular tone, and adrenocorticotropin (ACTH) secretion (De Rouffignac et al. 1991, de Keyzer et al. 1996, Szczepanska-Sadowska 1996) while OT stimulates milk ejection and enhances uterine contractility during parturition (Chibbar et al. 1993, Nishimori et al. 1996). In the central nervous system, AVP is involved in thermoregulation, learning and memory processes, social recognition, and aggressive behavior (de Wied et al. 1993, Alescio-Lautier \& Soumireu-Mourat 1998, Rose \& Moore 2002) while OT plays a crucial role in sexual activity and induces maternal behavior (Pedersen \& Prange 1979, Ivell et al. 1997). The effects of AVP and OT are mediated through four types of $\mathrm{G}$ protein-coupled receptors (GPCRs), i.e. the AVP receptors V1aR, V2R and V1bR (also 
called V3R) (Lolait et al. 1992, Morel et al. 1992, Sugimoto et al. 1994), and the OT receptor (OTR) (Kimura et al. 1992). These various membrane receptor subtypes differ in their tissue distribution, their relative affinity for a broad range of synthetic analogs, and their signaling mechanisms (Barberis et al. 1998, Gimpl \& Fahrenholz 2001). At the periphery, $\mathrm{VlaR}$ is primarily located on vascular smooth muscle cells and hepatocytes (Morel et al. 1992), V1bR is exclusively present in pituitary corticotrophs (Sugimoto et al. 1994, de Keyzer et al. 1996), V2R is found in the kidney (Lolait et al. 1992), and OTR is expressed in smooth muscle cells of the uterus (Kimura et al. 1992). All four receptor types are also expressed in the central nervous system (Burbach et al. 1995). Stimulation of VlaR, V1bR and OTR activates the phospholipase $\mathrm{C}$ /protein kinase $\mathrm{C}$ (PLC/PKG) signaling pathway, while stimulation of $\mathrm{V} 2 \mathrm{R}$ activates the adenylyl cyclase/ protein kinase A (AC/PKA) pathway (Liu \& Wess 1996, Gimpl \& Fahrenholz 2001).

AVP and OT belong to a large family of nonapeptides that encompasses at least 12 members (Acher et al. 1995). In most non-mammalian vertebrates including lungfish, amphibians, reptiles and birds, the AVP counterpart is vasotocin (VT; $\left[\mathrm{Hl}^{3}\right] \mathrm{AVP}$ ) and the OT counterpart is mesotocin (MT; $\left.\left[\mathrm{Ile}^{8}\right] \mathrm{OT}\right)$. In the frog, VT and MT are expressed in both hypothalamic and extrahypothalamic cell bodies (González \& Smeets 1992), indicating that, in amphibians as in mammals, VT and MT may act both as neurohormones and neurotransmitters. Indeed, it is firmly established that both VT and MT regulate osmotic and electrolyte balance, VT being an anti-diuretic hormone while MT acts as a diuretic agent (Pang \& Sawyer 1978, Warburg 1995). Concurrently, it has been shown that VT is expressed in chromaffin cells in the frog adrenal gland and that synthetic VT stimulates steroid secretion by frog adrenocortical cells (Larcher et al. 1989, 1992a, 1992b). There is also clear evidence that VT is involved in reproductive behavior in amphibians (Moore et al. 2000, Rose \& Moore 2002), and sexual dimorphism in the distribution of VT-containing neurons has been reported in the frog brain (Boyd et al. 1992).

In spite of the diverse and crucial roles of VT and MT in lower vertebrates, little is known regarding the structure, pharmacological profile, distribution and regulation of their receptors. To date, the VT receptor (VTR) has been character- ized in several non-mammalian species, including the white sucker Catostomus commersoni (Mahlmann et al. 1994), the Pacific salmon Oncorhynchus kisutch (Mahlmann et al. 1994), the cave-dwelling fish Astyanax fasciatus (Mahlmann et al. 1994), the euryhaline flounder Platichthys flesus (Warne 2001), the anuran Xenopus laevis (Mahlmann et al. 1994), and the domestic chicken Gallus gallus (Tan et al. 2000). An MT receptor (MTR) has also been cloned in the giant toad Bufo marinus (Akhundova et al. 1996). However, the sites of expression, the coupling mechanisms and the regulation of VTR and MTR have not been thoroughly investigated in non-mammalian vertebrates.

In the present study, we have cloned the cDNAs encoding the MTR and the Vla-type VTR in two species of frog, the bullfrog Rana catesbeiana and the European green frog Rana esculenta, a hybrid between Rana ridibunda and Rana lessonae. We have characterized the ligand sensitivity and signal transduction mechanisms of Rana catesbeiana VTR and MTR and we have compared the pharmacological profiles of frog VTR and MTR with those of their mammalian counterparts. Further, we have determined the distribution of VTR and MTR mRNAs in the brain and pituitary of Rana esculenta.

\section{Materials and methods}

\section{Peptides}

Synthetic peptides including AVP, OT, VT, MT, the V1 agonist $\left(\left[\mathrm{Phe}^{2}, \mathrm{Orn}^{8}\right] \mathrm{OT}\right)$, the V2 agonist ([deamino-Cys $\left.\left.{ }^{1}, \mathrm{Val}^{4}{ }^{4} \mathrm{D}-\mathrm{Arg}^{8}\right]-\mathrm{AVP}\right)$, the $\mathrm{Vla}$ antagonist $\left(\left[\mathrm{d}\left(\mathrm{CH}_{2}\right)_{5}{ }^{1}, \mathrm{Tyr}(\mathrm{Me})^{2}\right] \mathrm{AVP}\right)$, the V2 antagonist $\left(\left[\mathrm{d}\left(\mathrm{CH}_{2}\right)_{5}{ }^{1}, \mathrm{D}-\mathrm{Ile}^{2}, \mathrm{Ile}^{4}\right] \mathrm{AVP}\right)$, and the OT antagonist $\quad\left(\left[\mathrm{d}\left(\mathrm{CH}_{2}\right)_{5}{ }^{1}, \mathrm{Tyr}(\mathrm{Me})^{2}, \mathrm{Thr}^{4}, \mathrm{Orn}^{8}\right.\right.$, desGly- $\left.\mathrm{NH}_{2}{ }^{9}\right] \mathrm{VT}$ ) were purchased from Bachem (Bubendorf, Switzerland). The OT agonist $\left(\left[\mathrm{Thr}^{4}, \mathrm{Gly}^{7}\right] \mathrm{OT}\right)$ was purchased from Sigma (St Louis, MO, USA).

\section{Plasmids}

The pcDNA3 expression vector was purchased from Invitrogen (San Diego, CA, USA). The pCMV $\beta$-Gal vector was obtained from Clontech (Palo Alto, CA, USA). The CRE-luc vector which contains four copies of the cyclic AMP-responsive element (CRE; TGACGTCA) was from Stratagene (La Jolla, CA, USA). The c-fos-luc vector, containing the $-711 \sim+45$ sequence of the 
Table 1 Oligonucleotide sequences of primers

\begin{tabular}{|c|c|c|}
\hline & Name & Oligonucleotide sequence \\
\hline \multicolumn{3}{|l|}{ Application } \\
\hline \multirow[t]{6}{*}{ Amplification of partial cDNA } & DGF1 & 5'-AA(G/A)CACCT(G/A)AGCAT(A/C/T)GC(C/T/A/G)GA(C/T) \\
\hline & DGF2 & $5^{\prime}-\mathrm{TT}(\mathrm{C} / \mathrm{T}) \mathrm{CA}(\mathrm{G} / \mathrm{A}) \mathrm{GT}(\mathrm{G} / \mathrm{T} / \mathrm{C}) \mathrm{CT}(\mathrm{G} / \mathrm{C} / \mathrm{T} / \mathrm{A}) \mathrm{CC}(\mathrm{G} / \mathrm{T} / \mathrm{C}) \mathrm{CAG}(\mathrm{C} / \mathrm{T}) \mathrm{T}(\mathrm{T} / \mathrm{G} / \mathrm{C})$ \\
\hline & DGF3 & 5'-GG(C/G)ATGTT(C/T)GC(G/C/T/A)TC(C/T)ACCTA(C/T) \\
\hline & DGR1 & $5^{\prime}-\mathrm{AA}(\mathrm{A} / \mathrm{G}) \mathrm{AA}(\mathrm{G} / \mathrm{C} / \mathrm{A} / \mathrm{T}) \mathrm{GG}(\mathrm{T} / \mathrm{C}) \mathrm{GCCCA}(\mathrm{A} / \mathrm{G}) \mathrm{CA}$ \\
\hline & DGR2 & $5^{\prime}-\mathrm{TCCCA}(\mathrm{C} / \mathrm{A} / \mathrm{G}) \mathrm{AC}(\mathrm{T} / \mathrm{G} / \mathrm{A})(\mathrm{G} / \mathrm{C})(\mathrm{T} / \mathrm{A}) \mathrm{CCACAT}(\mathrm{T} / \mathrm{C}) \mathrm{TG}$ \\
\hline & DGR3 & $5^{\prime}-\mathrm{CCA}(\mathrm{A} / \mathrm{C} / \mathrm{T} / \mathrm{G}) \mathrm{GGGTT}(\mathrm{A} / \mathrm{G}) \mathrm{CA}(\mathrm{A} / \mathrm{G}) \mathrm{CAGCTGTT}$ \\
\hline \multirow[t]{2}{*}{$5^{\prime}$-RACE of VTR } & VSR-PR & 5'-GACCTCTTGGTAGGCTGGTGGAGA \\
\hline & MSV-CR & 5'-AGCATGTAGGTAGACGCAAACAT \\
\hline \multirow[t]{2}{*}{$3^{\prime}-$ RACE of VTR } & VSR-SF & 5'-CAAGTGCAAAACCAAGAGAGGTGA \\
\hline & MVR-CF & 5'-GCCAAAATCAGGACAGTGAA \\
\hline \multirow[t]{2}{*}{ 5'-RACE of MTR } & MSR-NR & 5'-TGCCCACAGAGGTGAGGGAGA \\
\hline & MSR-PR & 5'-ACACAATCCGACCGTCTATGTAAG \\
\hline \multirow[t]{2}{*}{ 3'-RACE of MTR } & MSR-NF & 5'-GTCCGTCTACATCATCCCAGTCC \\
\hline & MSR-SF & 5'-TCGCCTGAAGACGGTCTGTGAGAG \\
\hline \multirow[t]{2}{*}{ Cloning of VTR ORF } & VTR-F & 5'-TGCGAATTCACTATGGGCTTCTCTAAACTGGG \\
\hline & VTR-R & 5'-CCTGTTCTCGAGCGGTCAGATTTGCAGGGGCAG \\
\hline \multirow[t]{2}{*}{ Cloning of MTR ORF } & MTR-F & 5'-GACGAATTCATCATGGGGGGCTTTGACAGCGACTGTAT \\
\hline & MTR-R & 5'-GGGCTCGAGGGGTCACACTGTCGATGGTTGAGTGAT \\
\hline \multirow[t]{2}{*}{ MTR tissue distribution } & MTPA-F & 5'-AGACGGTCGGATTGTGTCTAC \\
\hline & MTPA-R & 5'-CTCGGGACAAGGTGGCTCTTT \\
\hline \multirow[t]{2}{*}{ VTR tissue distribution } & VTPA-F & 5'-CTGATGATCGGTAGCGCTTGG \\
\hline & VTPA-R & 5'-CTTGAAATGGTCCTCACGCTG \\
\hline
\end{tabular}

human c-fos promoter constructed in the pFLASH vector, was a kind gift from Dr R Prywes, Columbia University, NY, USA.

\section{Animals and tissue preparation}

Male and female bullfrogs (R. catesbeiana, 100-120 g body weight) were obtained from a local supplier (BCPC, Taein, Korea). Male european green frogs (R. esculenta, 30-40 g body weight) were obtained from a commercial source (Couétard, Saint-Hilaire de Riez, France). The animals were kept in glass tanks supplied with tap water under simulated natural conditions. Frogs were killed by cervical transection and the tissues were quickly dissected, immediately frozen in liquid nitrogen, and stored at $-80{ }^{\circ} \mathrm{C}$ until use. Animal manipulations were performed according to the recommendations of the ethical committees at our institutions and under the supervision of authorized investigators.

\section{RNA isolation and RT-PCR}

Total RNA was extracted from either the forebrain or the pituitary of five male $R$. catesbeiana and five male $R$. esculenta by using Trireagent (Sigma) according to the manufacturer's instructions. Poly $(\mathrm{A})^{+}$RNA was purified from total RNA by using QIAGEN Oligotex mRNA kit (QIAGEN, Chatsworth, CA, USA). The RNAs from different tissues (obtained from five male and five female $R$. catesbeiana) were reverse transcribed by using the random hexamer and MMTV reverse transcriptase (Promega Corp., Madison, WI, USA). The cDNAs served as templates for subsequent PGR amplification of partial clones by using several sets of forward (DGF1, DGF2, DGF3) and reverse (DGR1, DGR2, DGR3) degenerate primers (Table 1). PGR conditions were: denaturation at $94{ }^{\circ} \mathrm{C}$ for $5 \mathrm{~min}$, followed by 35 cycles at $94^{\circ} \mathrm{C}$ for $30 \mathrm{~s}, 55^{\circ} \mathrm{C}$ for $30 \mathrm{~s}$, and $72{ }^{\circ} \mathrm{C}$ for $50 \mathrm{~s}$. PCR products of expected sizes were excised, purified and subcloned into pGEM-T easy vector (Promega). Positive clones were isolated and purified by using a QIAGEN Plasmid Miniprep Kit (QIAGEN). Plasmids containing the proper inserts were analyzed for their DNA sequence by the dideoxy chain-termination method, using the DNA sequencing kit (USB Corp., Cleveland, $\mathrm{OH}, \mathrm{USA})$. 


\section{Cloning of the full-length cDNAs by rapid amplification of cDNA ends (RACE)}

Two sets of gene-specific primers (GSPs) were designed for each VTR and MTR on the basis of the partial sequences of the cDNAs obtained by RT-PCR. To obtain the full-length VTR cDNA, the primers sets VSR-PR and MVR-CR (for 5'-RACE), and VSR-SF and MVR-CF (for 3'-RACE) were used (Table 1). For the MTR, the primer sets MSR-NR and MSR-PR (for 5'-RACE), and MSR-NF and MSR-SF (for 3'-RACE) were used (Table 1). Poly(A)-rich RNA purified from the forebrain and pituitary was used to synthesize adapter-ligated double-stranded cDNA by using the Marathon cDNA Amplification Kit (Clontech). Next, 5'- and 3'-RACE was performed by using the GSPs in combination with the adapter primers AP1 and AP2 respectively. RACE products were cloned in pGEM-T easy vector (Promega). After obtaining the proper 5'- and 3'-RACE products, gene specific forward and reverse primers were designed to obtain the full-length cDNAs which were inserted into the pcDNA3 expression vector at the EcoRI and XhoI enzyme sites. The rat V1aR and V2R cDNAs were amplified through PCR from rat liver and kidney tissues respectively, and inserted at the EcoRI and XhoI sites of the pcDNA3. The human OTR cloned in the PRK5 plasmid was a kind gift from Dr Thierry Durroux (INSERM U469, Montpellier, France). The human OTR was cut at BamHI and XhoI sites and reinserted into the pcDNA3 expression vector.

\section{Luciferase assays}

GV-1 cells were maintained in Dulbecco's modified Eagle's medium (DMEM) in the presence of $10 \%$ fetal bovine serum. For luciferase assays, cells were plated in 24-well plates 1 day before transfection and transfected with SuperFect reagent (QIAGEN) according to the manufacturer's instructions. Approximately $48 \mathrm{~h}$ after transfection, cells were treated with the respective ligands for $6 \mathrm{~h}$. For c-fos promoter-driven luciferase assay, cells were maintained in serum-free DMEM 16-18 h before treatment with the ligand as previously described (Seong et al. 2003). Cells were harvested $6 \mathrm{~h}$ after ligand treatment and luciferase activity in cell extracts was determined using a luciferase assay system according to the standard method in a
Lumat LB9501 (EB \& G, Berhold, Germany). The luciferase values were normalized by the $\beta$-galactosidase values. Transfection experiments were performed in duplicate and repeated at least three times. All data are presented as means \pm S.E.M.

\section{VTR and MTR expression in peripheral tissues}

Tissues were collected from five male $R$. catesbeiana (five females for the oviduct) and stored at $-80{ }^{\circ} \mathrm{C}$. The first-strand cDNA was prepared using the random hexamer and MMTV reverse transcriptase (Promega). To determine the tissue distribution of VTR and MTR, the primer sets MTPA-F and MTPA-R, and VTPA-F and VTPA-R respectively were used (Table 1). PCR conditions were: denaturation at $94{ }^{\circ} \mathrm{C}$ for $3 \mathrm{~min}$, followed by 30 cycles at $94{ }^{\circ} \mathrm{C}$ for $30 \mathrm{~s}, 60{ }^{\circ} \mathrm{C}$ for $30 \mathrm{~s}$ and $72{ }^{\circ} \mathrm{C}$ for $50 \mathrm{~s}$.

\section{In situ hybridization histochemistry}

In situ hybridization was performed as previously described (Alexandre et al. 1999). Briefly, six adult male frogs, $R$. esculenta, were anesthetized and perfused transcardially with $50 \mathrm{ml} 0 \cdot 1 \mathrm{M}$ phosphate buffer $(\mathrm{PB}, \mathrm{pH} 7 \cdot 4)$ containing 4\% paraformaldehyde. The brain with the attached pituitary was rapidly dissected and post-fixed in the same fixative for $24 \mathrm{~h}$ at $4{ }^{\circ} \mathrm{C}$. The tissues were rinsed for $12 \mathrm{~h}$ in PB containing 15\% sucrose and $24 \mathrm{~h}$ in $\mathrm{PB}$ containing $30 \%$ sucrose. The brains were placed in an embedding medium (O.C.T. Tissue Teck; Leica, Nussloch, Germany) and frozen at $-80{ }^{\circ} \mathrm{C}$. Frontal sections $(12 \mu \mathrm{m}$ thick) were cut in a cryostat (Frigocut 2800E; Reichert-Jung, Nussloch, Germany) and mounted on poly-L-lysine- and gelatin-coated slides. Partial VTR (nt 424-934) and MTR (nt 271-884) cDNA obtained from $R$. esculenta were subcloned into the pGME-T vector between SpeI and NcoI sites, and sense and antisense riboprobes were generated by in vitro transcription using T7 and Sp6 RNA polymerases in the presence of $\left[{ }^{35} \mathrm{~S}\right] \mathrm{UTP}$ (Combination Systems; Promega). Sections were incubated for $10 \mathrm{~min}$ in $0 \cdot 1 \mathrm{M}$ triethanolamine $/ 0 \cdot 9 \% \mathrm{NaCl}(\mathrm{pH} 8 \cdot 0) / 0 \cdot 25$ acetic anhydride, rinsed in $2 \times \mathrm{SSC}$, and incubated for 60 min with prehybridization buffer $(\mathrm{pH} 7 \cdot 5)$ containing $50 \%$ formamide, $0.6 \mathrm{M} \mathrm{NaCl}, 10 \mathrm{mM}$ Tris-HCl $(\mathrm{pH} 7 \cdot 5), 1 \times$ Denhart, $0.02 \%$ Ficoll, 
$0.02 \%$ polyvinylpyrrolidone, $0.02 \%$ bovine serum albumin, $1 \mathrm{mM}$ EDTA (pH 8.0), $550 \mu \mathrm{g} / \mathrm{ml}$ denatured salmon sperm DNA, and $50 \mu \mathrm{g} / \mathrm{ml}$ yeast tRNA. Hybridization was performed overnight at $55^{\circ} \mathrm{C}$ in the same buffer (except for salmon sperm DNA whose concentration was reduced to $60 \mu \mathrm{g} /$ $\mathrm{ml}$ ) supplemented with $10 \mathrm{mM}$ dithiothreitol, $10 \%$ dextran sulfate, and $1.5 \times 10^{7}$ c.p.m. $/ \mathrm{ml}$ heatdenatured RNA riboprobes. Tissue sections were then washed in $2 \times \mathrm{SSC}$ at $55^{\circ} \mathrm{C}$ and treated with ribonuclease A $(50 \mu \mathrm{g} / \mathrm{ml})$ for $60 \mathrm{~min}$ at $37^{\circ} \mathrm{C}$. High stringency washes were performed in $0.01 \times \mathrm{SSC}$ containing $14 \mathrm{mM} \beta$-mercaptoethanol and $0.05 \%$ sodium pyrophosphate at $60{ }^{\circ} \mathrm{C}$. The tissue sections were dehydrated in ethanol and exposed onto Hyperfilm $\beta$-max (Amersham Pharmacia Biotech, Orsay, France) for 2 weeks. The optic density of the autoradiograms was quantified by means of a computer-assisted image analyzer (SAMBA Autoradio 4.10; SAMBA Technologies, Meylan, France). To identify anatomical structures, the sections were stained with hematoxylin/eosin. Nomenclature of frog brain structures was based on the atlas of Neary \& Northcutt (1983).

\section{Results}

\section{Cloning of full-length VTR and MTR}

Using degenerate primers we obtained two partial PCR fragments for $R$. catesbeiana VTR and MTR with $520 \mathrm{bp}$ and $630 \mathrm{bp}$ respectively. The $5^{\prime}$ - and $3^{\prime}$-cDNA end sequences for each receptor were obtained by performing RACE using gene-specific primers. The full-length bullfrog VTR and MTR consisted of 1257 and 1152 nucleotides that encoded proteins of 419 and 384 amino acids respectively (Fig. 1). We also identified full-length sequences for the $R$. esculenta VTR having the same amino acid sequence as the bullfrog VTR but differing by five nucleotides. We cloned a partial sequence for $R$. esculenta MTR that showed 98\% sequence similarity with the bullfrog MTR. The hydropathy analysis of frog VTR and MTR revealed the presence of seven stretches of hydrophobic amino acid residues corresponding to the seven transmembrane domains. Potential sites for N-linked glycosylation and phosphorylation were present in both the VTR and MTR. Several putative sites for phosphorylation by $\mathrm{PKC}$, casein kinase II, and G protein-coupled receptor kinase (GRK) were seen in the intracellular loops and C-terminal tails of the receptors (Fig. 1). The frog VTR showed the highest sequence identity (63\%) with the flounder VTR and relatively high sequence identity (58\%) with the human VlaR. The frog MTR exhibited the highest sequence identity $(85 \%)$ with the giant toad MTR and a relatively high degree of homology $(67 \%)$ with the human OTR. The VTR and MTR shared 47\% sequence identity with each other (Table 2).

\section{Ligand selectivity and signal transduction pathways of frog VTR and MTR}

The open reading frames of the $R$. catesbeiana VTR and MTR were subcloned in the pcDNA3, a mammalian expression vector, and the VTR and MTR cDNAs were transiently transfected in CV-1 cells in combination with the CRE-luc or c-fos-luc reporter vectors. We have previously demonstrated that CRE-luc and c-fos-luc reporter systems are useful tools to discriminate AC/PKA and PLC/ PKC signaling pathways respectively (Oh et al. 2003, Seong et al. 2003). In the absence of frog VTR or MTR, neither CRE- nor c-fos-promoterdriven transcriptional activity in $\mathrm{CV}-1$ cells was induced by the nonapeptide ligands VT, AVP, MT and OT, indicating that $\mathrm{CV}-1$ cells do not naturally express the endogenous receptors for these ligands (data not shown).

In $\mathrm{CV}-1$ cells transfected with the VTR cDNA, VT induced a concentration-dependent increase of both CRE- and c-fos-promoter-driven luciferase activity (Fig. 2A and B). The other nonapeptide ligands tested also stimulated VTR activity with the following rank order of potency: $\mathrm{OT}>\mathrm{AVP} \approx \mathrm{MT}$ (Fig. 2A and B). In CV-1 cells transfected with the MTR cDNA, the nonapeptide ligands did not induce CRE-driven luciferase activity (Fig. 2G) but substantially increased c-fos-promoter-driven luciferase activity with the following rank order of potency: MT $>$ OT $>$ VT $>$ AVP (Fig. 2D). These data indicated that frog VTR and MTR have different functional characteristics with respect to signal transduction and ligand sensitivity: frog VTR couples to both the PLG/PKG and AC/ PKA pathways, while frog MTR preferentially couples to the PLG/PKG pathway but marginally to the AC/PKA pathway. Frog VTR and MTR exhibited the highest sensitivity to the 


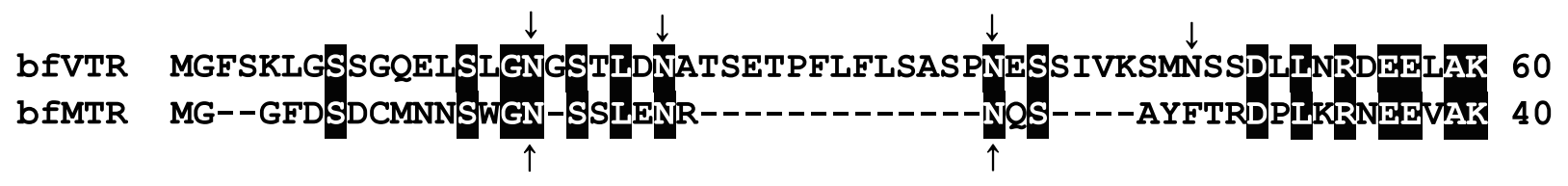

TMDI

TMDII

bfVTR IFIAVLAVIFVAAVLGNCSVILGLYKSKKKMSRMHLFIKHLSLADLVVAFFOVLPQLCŴ̉E 120

bFMTR VEVAVLALILILALVGNICVIIAIHINRRKHSRMYFFMKHLSIADLVVALFQVLPQIINDD 100

TMDIII

bEVTR ITYREYGPDFLCRI IRHLQVFGMFASTYMLVVMTADRYIAICHPLKTLHQPTKRSYLMIG 180 bFMTR ITFRFYAPDIMCRLVKYLQVVGMFAPTYMLLLMISLDRCLẬVCQPLRSLHRRSDCVYVLV- 159

TMDIV

TMDV

bFVTR SAWIISFILSTPQYGIFYLKDLEDGVYDCWADFISPKGLKAYITKITISIFVVPVIIILT 240 bFMTR -TWI ISFLLSIPOIVIFSLTSVGNGVHDCLADFIOPWGLKAYITWITLSVYIIPVLIISV 218

TMDVI

bFVTR CYGFICYNIWRNIKCKTKRGETDRKRSNGLLSTS-VSSVRTISRARIRTVKMTFVIVTAY bFMTR CYGLISFKIWONIRLKTVCESNLRLSSNKRATLSRVSSVRLISKAKIRTVKMTEIIVIAY

O 0 ○

278

TMDVII

bEVTR IICWTPYFTIQMWSVYADNTNWIENENTVVTVSALIASLNSCCNPWIYMFFSGHLLQDFI 359 bFMTR IICKTPFEYVQMKSVWDPEA---PKEASLFI IAMLLGSLNSCCNPWIYMLFTGHLFHDLL 335

\section{bFVTR LSVLCCSRFKHNLSKEDSDSSTRRQTSFTRIQTRSPTHSTDTWKDSPKSSRSIKFLPLQI 419 bFMTR QRLLCCSARYLKAKQQGSDLSASSRKS----------NSSTFVLSRKSSSQKSITQPSTV- 384}

Figure 1 Comparison of the deduced amino acid sequences of the MTR and VTR. Black-shaded residues are identical between two receptors. Gaps introduced for optimal alignment are indicated as dashes. The putative transmembrane domains are indicated above the aligned sequence. The symbols indicate specific sites ( $\downarrow$, N-glycosylation sites for bullfrog (bf)VTR; $\uparrow, N$-glycosylation sites for bfMTR; $\bigcirc$, PKC phosphorylation sites for bfVTR; - PKC phosphorylation sites for bfMTR; $\square$, casein kinase II phosphorylation sites for bfVTR; $\square$, casein kinase II phosphorylation sites for bfMTR. A GRK phosphorylation motif is underlined in the VTR sequence.

homologous ligands but low sensitivity to the opposite ligand.

Comparison of the pharmacological profiles of frog versus mammalian nonapeptide receptors

The pharmacological characteristics of $R$. catesbeiana VTR and MTR were compared with the mammalian receptors, rat V1aR, V2R and human OTR. Both rat V1aR and V2R were able to induce CRE- and c-fos promoter-driven luciferase activity in response to the nonapeptides (Fig. 3). As expected, VlaR and V2R exhibited the highest sensitivity towards AVP. However, VlaR and $\mathrm{V} 2 \mathrm{R}$ showed a slight difference in the rank order of ligand sensitivity: $\mathrm{AVP}>\mathrm{VT}>\mathrm{OT} \approx \mathrm{MT}$ for $\mathrm{VlaR}$, and $\mathrm{AVP}>\mathrm{VT} \approx \mathrm{OT}>\mathrm{MT}$ for $\mathrm{V} 2 \mathrm{R}$ (Fig. 3A-D and Table 3). Interestingly, the human OTR substantially increased c-fos-promoter-driven luciferase activity but failed to induce GRE-driven 
Table 2 Amino acid identity of frog VTR and frog MTR with other members of AVP/OT receptor family

\begin{tabular}{|c|c|c|c|}
\hline & Species & $\begin{array}{l}\% \text { Identity with } \\
\text { frog VTR }\end{array}$ & $\begin{array}{l}\% \text { Identity with } \\
\text { frog MTR }\end{array}$ \\
\hline \multicolumn{4}{|l|}{$\begin{array}{l}\text { Receptor type } \\
\text { (Genbank accession number) }\end{array}$} \\
\hline VTR (AF184966) & Platichthys flesus (European flounder) & 63 & 46 \\
\hline VTR $(X 76321)$ & Catostomus commersoni (white sucker) & 56 & 46 \\
\hline VT1R (AF147743) & Gallus gallus (chicken) & 42 & 40 \\
\hline VT1bR (AY008272) & Gallus gallus (chicken) & 41 & 45 \\
\hline VT2R (AB073979) & Hyla japonica (Japanese treefrog) & 39 & 39 \\
\hline MTR (X93313) & Bufo marinus (giant toad) & 49 & 86 \\
\hline MTR (AB073980) & Hyla japonica (Japanese treefrog) & 48 & 85 \\
\hline ITR (X87783) & Catostomus commersoni (white sucker) & 45 & 64 \\
\hline V1aR (U19906) & Homo sapiens (man) & 58 & 44 \\
\hline V1aR (Z11690) & Rattus norvegicus (Norway rat) & 55 & 44 \\
\hline OTR (X64878) & Homo sapiens (man) & 43 & 67 \\
\hline OTR (L81169) & Rattus norvegicus (Norway rat) & 44 & 67 \\
\hline V2R (AF101727) & Homo sapiens (man) & 36 & 37 \\
\hline V2R (Z22758) & Rattus norvegicus (Norwary rat) & 36 & 39 \\
\hline V1bR (AF101726) & Homo sapiens (man) & 43 & 48 \\
\hline V1bR (D45400) & Rattus norvegicus (Norway rat) & 42 & 46 \\
\hline
\end{tabular}

luciferase activity. The OTR responded better to OT and MT than to VT and AVP (Fig. 3E and F).

The rat V2R increased GRE-driven luciferase activity slightly better than c-fos-promoter-driven luciferase activity, while all other receptors increased c-fos-promoter-driven luciferase activity more strongly. Thus, in subsequent experiments, we chose the CRE-luc reporter system for characterizing rat $\mathrm{V} 2 \mathrm{R}$, and the c-fos-luc reporter system for characterizing rat VlaR, human OTR, and frog VTR and MTR. The effects of mammalian AVP and OT agonists (Fig. 4) and antagonists (Fig. 5) on VTR and MTR were examined. The Vla agonist $\left(\left[\mathrm{Phe}^{2}, \mathrm{Orn}^{8}\right] \mathrm{OT}\right)$ was able to activate both VTR and MTR while the V2 agonist ([deamino-Cys $\left.\left.{ }^{1}, \mathrm{Val}^{4}{ }^{4} \mathrm{D}-\mathrm{Arg}^{8}\right] \mathrm{AVP}\right)$ was not. The OT agonist ([Thr $\left.\left.{ }^{4}, \mathrm{Gly}^{7}\right] \mathrm{OT}\right)$ failed to activate either VTR or MTR (Fig. 4A and B). The Vla and V2 agonists activated rat $\mathrm{VlaR}$ with similar potency while the $\mathrm{V} 2$ agonist was much more potent than the V1a agonist to stimulate rat V2R. The OT agonist did not activate rat $\mathrm{VlaR}$ at all but partially activated V2R (Fig. 4C and D). The OTR was activated by the OT agonist alone but not by the V1 or V2 agonist (Fig. 4E). The V1a antagonist $\left(\left[\mathrm{d}\left(\mathrm{CH}_{2}\right)_{5}{ }^{1}, \mathrm{Tyr}(\mathrm{Me})^{2}\right] \mathrm{AVP}\right)$, the $\mathrm{V} 2$ antagonist $\left(\left[\mathrm{d}\left(\mathrm{CH}_{2}\right)_{5}{ }^{1}, \mathrm{D}-\mathrm{Ile}^{2}, \mathrm{Ile}^{4}\right] \mathrm{AVP}\right)$, and the OT antagonist $\quad\left(\left[\mathrm{d}\left(\mathrm{CH}_{2}\right)_{5}{ }^{1}, \mathrm{Tyr}(\mathrm{Me})^{2}, \mathrm{Thr}^{4}, \mathrm{Orn}^{8}\right.\right.$, desGly- $\left.\mathrm{NH}_{2}{ }^{9}\right] \mathrm{VT}$ ) had no effect on VT-induced VTR activity (Fig. 5A) but inhibited MT-induced MTR activity with the following rank order of potency: $\mathrm{V} 1 \mathrm{a}$ antagonist $>\mathrm{OT}$ antagonist $>\mathrm{V} 2$ antagonist (Fig. 5B). The V la antagonist selectively suppressed AVP-induced rat V1aR activity, while the V2 antagonist specifically inhibited AVP-induced rat V2R activity (Fig. 5C and D). All three antagonists blocked the human OTR activity in the following rank order of potency: OT antagonist $>\mathrm{Vla}$ antagonist $>\mathrm{V} 2$ antagonist (Fig. 5E). These results indicated that the pharmacological characteristics of frog VTR and MTR markedly differ from each other (Table 3) but their pharmacological characteristics are very similar to those of their mammalian homologs.

\section{Tissue distribution of frog VTR and MTR}

In order to determine the tissue expression of frog VTR and MTR in $R$. catesbeiana, RT-PGR was performed with 30 cycles of amplification (Fig. 6). The VTR mRNA was abundant in the forebrain, hypothalamus, distal lobe of the pituitary, heart, adrenal gland, kidney and oviduct, while the MTR mRNA was primarily expressed in the forebrain, hypothalamus, neurointermediate lobe of the pituitary, adrenal gland, kidney and testis. However, after 33 cycles of amplification both VTR and MTR transcripts could be detected in all the tissues 

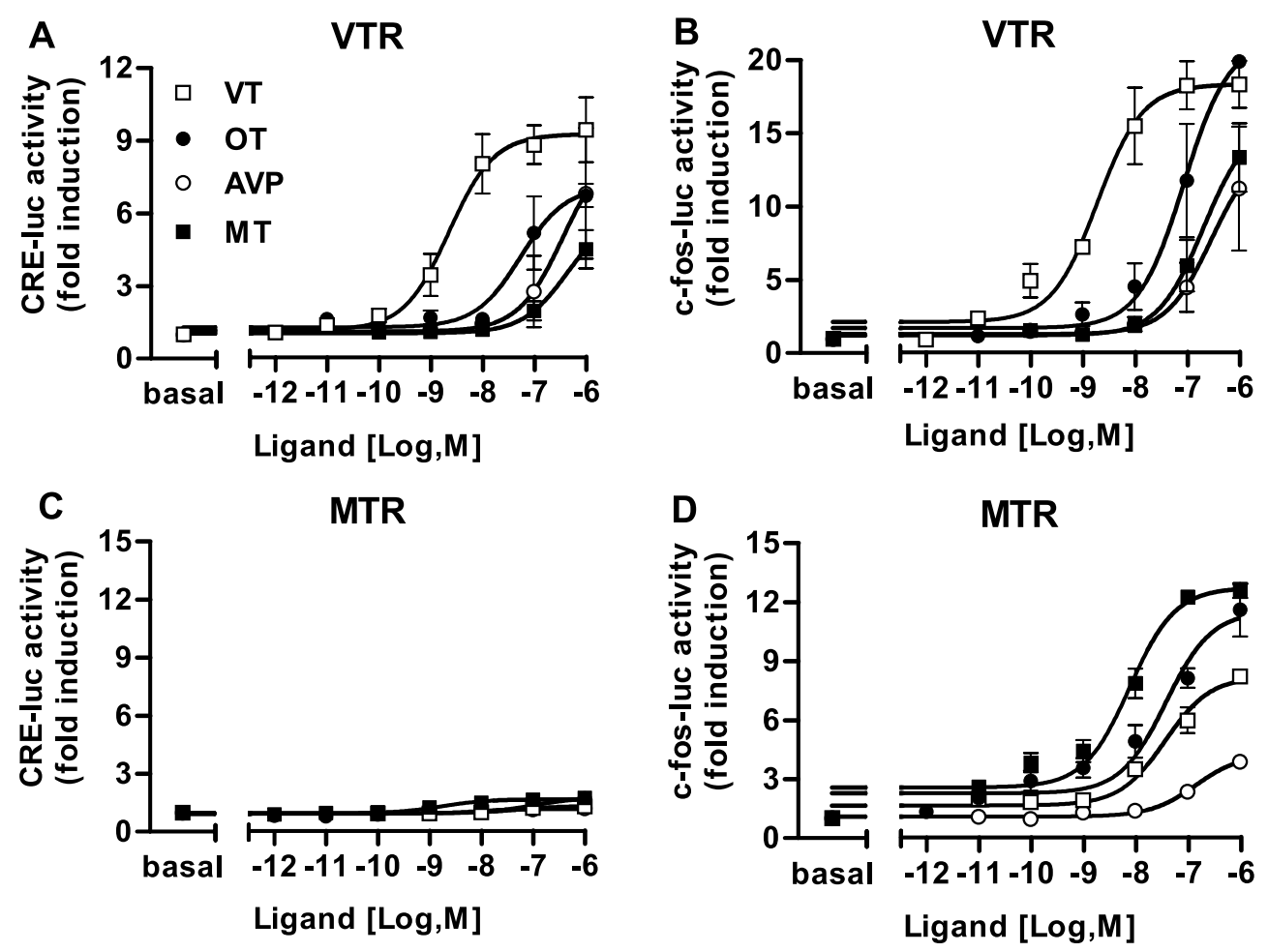

Figure 2 Effects of various natural nonapeptides on bullfrog VTR and MTR. The plasmids containing the VTR or MTR cDNA were cotransfected with (A and C) CRE-luc or (B and D) c-fos-luc reporter vectors into CV-1 cells along with $\beta$-gal as an internal control. Forty-eight hours after transfection, cells were treated with graded concentrations of ligands: AVP $(\bigcirc)$, VT ( $\square)$, OT (๑), and MT ( $\square$ ) for $6 \mathrm{~h}$ and luciferase activity was determined. The results represent the means \pm S.E.M. of three independent experiments.

examined (data not shown). To rule out the possible contamination of genomic DNA, a similar set of experiments was conducted using RNA samples that were not reverse transcribed, showing no amplification of the VTR or MTR cDNAs (data not shown).

\section{Distribution of VTR and MTR mRNAs in the frog brain and pituitary}

The localization of VTR and MTR mRNAs in the brain and pituitary of $R$. esculenta was determined by in situ hybridization histochemistry using ${ }^{35}$ S-labeled antisense riboprobes. The distribution and relative density of the hybridization signals are summarized in Table 4.

\section{VTR TRNA}

In the telencephalon, a strong hybridization signal was observed in the nucleus accumbens (Fig. 7A), the ventral striatum (Fig. 7A), the lateral pallium (Fig. 7B), and the lateral amygdala (Fig. 7B and C). A moderate density of VTR mRNA was seen in the lateral septum (Fig. 7A), the dorsal striatum (Fig. 7A), and the medial and dorsal pallium (Fig. 7A and B). A weak hybridization signal was also detected in the olfactory tubercle, the internal granular layer of the olfactory bulb, the medial septum (Fig. 7A), the anterior entopeduncular nucleus (Fig. 7B), and the medial amygdala (Fig. 7B).

In the diencephalon, a strong VTR hybridization signal was observed in the anterior preoptic area (Fig. 7B), the ventral and dorsal aspects of the magnocellular preoptic nucleus (Fig. 7B), the ventral hypothalamic nucleus (Fig. $7 \mathrm{E}$ and $\mathrm{F}$ ), the posterior tuberculum (Fig. $7 \mathrm{E}$ and F), the dorsal hypothalamic nucleus (Fig. 7F), the nucleus of the periventricular organ (Fig. $7 \mathrm{~F}$ ), and the ventromedial thalamic nucleus (Fig. 7D and E). Moderate labeling was visualized in the 

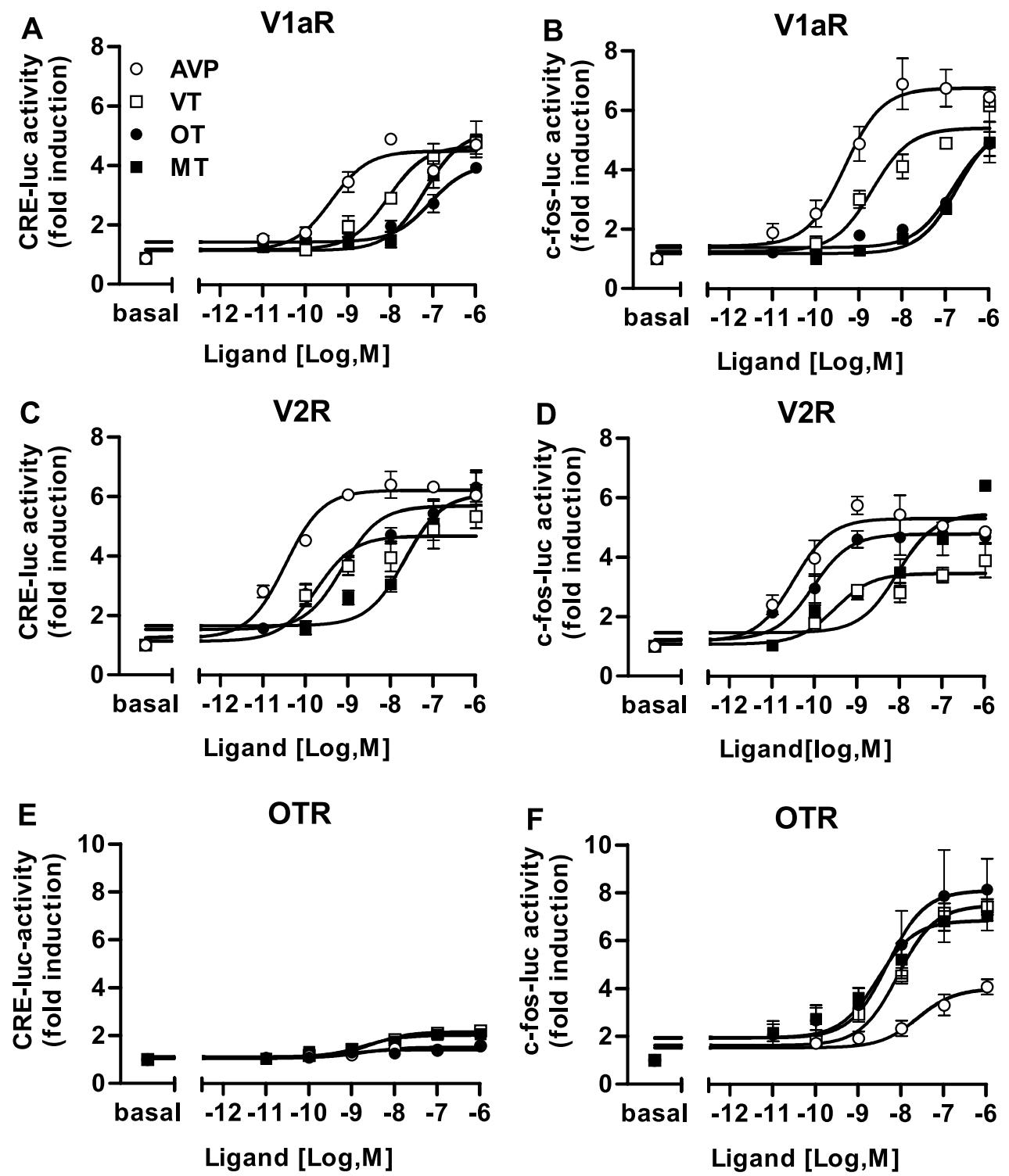

Figure 3 Effects of various natural nonapeptides on rat V1aR, rat V2R, and human OTR. The plasmids containing receptor cDNA were cotransfected with (A, C and E) CRE-luc or $(\mathrm{B}, \mathrm{D}$ and $\mathrm{F}$ ) c-fos-luc reporter vectors into $\mathrm{CV}$ - 1 cells along with $\beta$-gal as an internal control. Forty-eight hours after transfection, cells were treated with graded concentrations of ligand, AVP (O), VT ( $\square$ ), OT (๑), and MT ( $\square$ ) for $6 \mathrm{~h}$ and luciferase activity was determined.

dorsal and ventral habenular nuclei (Fig. 7G), the suprachiasmatic nucleus (Fig. 7D), the central thalamic nucleus (Fig. 7E), and the posterior thalamic nucleus (Fig. $7 \mathrm{E}$ and $\mathrm{F}$ ). A positive VTR mRNA signal was also detected in the magnocellular preoptic nucleus (Fig. 7D) and in the anterior and ventrolateral thalamic nuclei (Fig. 7D).
In the mesencephalon, intense VTR mRNA signal was observed in the nucleus of the medial longitudinal fasciculus (Fig. 7G), the pretoral gray (Fig. 7G), and the internal layers of the optic tectum (Fig. $7 \mathrm{H})$. A moderate signal was found in the tectal lamina six (Fig. 7F and G), the pretectal gray (Fig. 7G), and the anterodorsal and anteroventral tegmental nuclei (Fig. $7 \mathrm{G}$ and $\mathrm{H}$ ). A weak 
Table $3 \mathrm{EC}_{50}$ and $\mathrm{IC}_{50}$ values of ligands treated in frog MTR and frog VTR. Data are means \pm S.E.M. of three independent experiments

\begin{tabular}{|c|c|c|c|c|c|}
\hline & $\mathrm{EC}_{50}(\log , \mathrm{M})$ & & & & \\
\hline & $\overline{\text { VTR }}$ & MTR & V1aR & V2R & OTR \\
\hline $\begin{array}{l}\text { Ligand } \\
\text { VT } \\
\text { MT } \\
\text { AVP } \\
\text { OT } \\
\text { V1a agonist } \\
\text { V2 agonist } \\
\text { OT agonist }\end{array}$ & $\begin{array}{c}-8 \cdot 71 \pm 0.18 \\
-6 \cdot 68 \pm 0.23 \\
-6.52 \pm 0.51 \\
-7.05 \pm 0 \cdot 19 \\
-7.81 \pm 0 \cdot 12 \\
\text { n.d. } \\
\text { n.d. } \\
\text { IC }_{50}(\log , M)\end{array}$ & $\begin{array}{l}-7.42 \pm 0.13 \\
-8 \cdot 10 \pm 0 \cdot 12 \\
-6 \cdot 83 \pm 0.02 \\
-7.41 \pm 0.19 \\
-7 \cdot 74 \pm 0.13 \\
\text { n.d. } \\
\text { n.d. }\end{array}$ & $\begin{array}{c}-8 \cdot 70 \pm 0 \cdot 20 \\
-6 \cdot 75 \pm 0 \cdot 18 \\
-9 \cdot 34 \pm 0 \cdot 19 \\
-6 \cdot 84 \pm 0 \cdot 14 \\
-7 \cdot 98 \pm 0 \cdot 16 \\
-7 \cdot 87 \pm 0 \cdot 16 \\
\text { n.d. }\end{array}$ & $\begin{array}{r}-9.73 \pm 0.24 \\
-7.67 \pm 0.30 \\
-10.47 \pm 0.12 \\
-9.14 \pm 0.19 \\
-7.87 \pm 0.11 \\
-11.45 \pm 0.22 \\
-6.33 \pm 0.18\end{array}$ & $\begin{array}{c}-8.09 \pm 0.12 \\
-8.57 \pm 0.22 \\
-7.63 \pm 0.29 \\
-8.33 \pm 0.36 \\
\text { n.d. } \\
\text { n.d. } \\
-7.27 \pm 0.09\end{array}$ \\
\hline $\begin{array}{l}\text { V1a antagonist } \\
\text { V2 antagonist } \\
\text { OT antagonist }\end{array}$ & $\begin{array}{l}\text { n.d. } \\
\text { n.d. } \\
\text { n.d. }\end{array}$ & $\begin{array}{l}-7 \cdot 18 \pm 0.29 \\
-6 \cdot 10 \pm 1.33 \\
-6 \cdot 54 \pm 0.42\end{array}$ & $\begin{array}{c}-9.61 \pm 0.19 \\
-8.01 \pm 0.73 \\
\text { n.d. }\end{array}$ & $\begin{array}{c}-7.05 \pm 0.24 \\
-10.06 \pm 0.16 \\
\text { n.d. }\end{array}$ & $\begin{array}{r}-7.91 \pm 0.31 \\
-6 \cdot 11 \pm 1 \cdot 01 \\
-10 \cdot 10 \pm 0 \cdot 19\end{array}$ \\
\hline
\end{tabular}

n.d., not determined.

hybridization signal was also detected in the torus semicircularis (Fig. 7H).

In the pituitary, moderate labeling was seen in the distal and intermediate lobes whereas the neural lobe was devoid of VTR mRNA signal (Fig. $7 \mathrm{H})$.

Control sections, taken at different levels of the brain and treated with the sense VTR probe, did
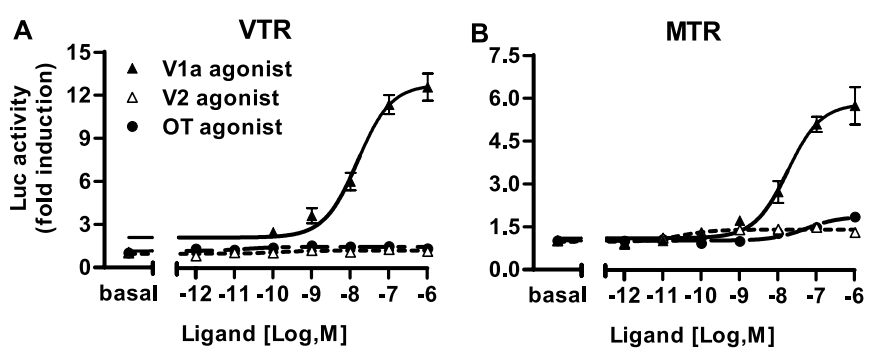

V2R

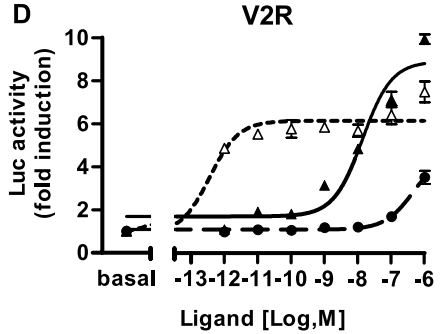

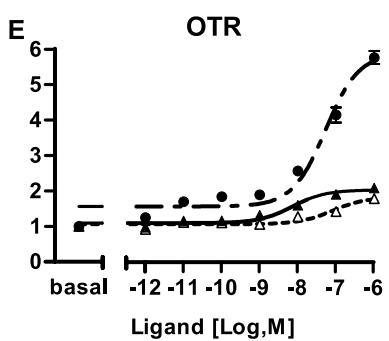

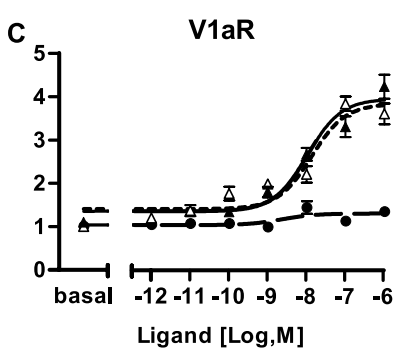

Ligand [Log,M]

Figure 4 Effects of nonapeptide agonists on (A) bullfrog VTR, (B) bullfrog MTR, (C) rat V1aR, (D) rat V2R, and (E) human OTR. In the case of VTR, MTR, rat V1aR, and human OTR, c-fos-luc reporter activity was determined, whereas for rat V2R, CRE-luc reporter activity was determined. Forty-eight hours after transfection, cells were treated with different concentrations of V1a $(\boldsymbol{\Delta})$, V2 $(\triangle)$, and OT $(\bullet)$ agonists for $6 \mathrm{~h}$. 


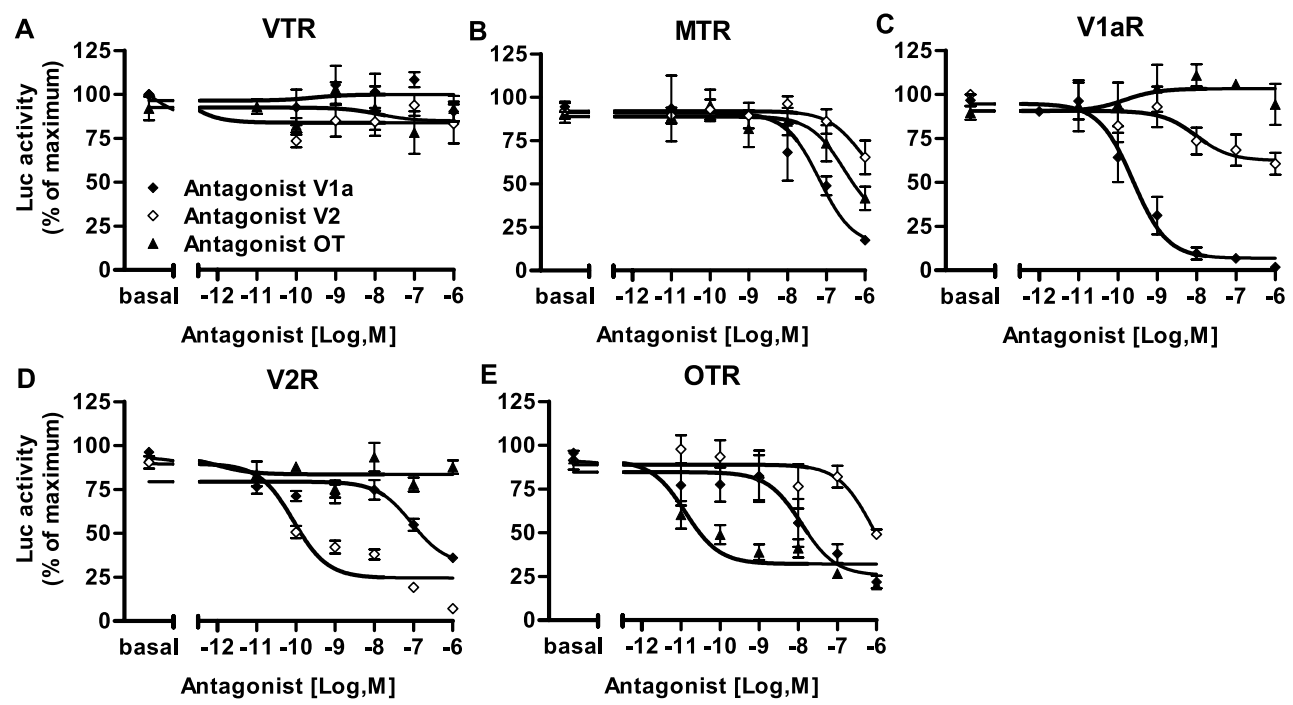

Figure 5 Effects of nonapeptide antagonists on (A) bullfrog VTR, (B) bullfrog MTR, (C) rat V1aR, (D) rat V2R, (E) and human OTR. In the case of VTR, MTR, rat V1a and human OT receptors, c-fos-luc reporter activity was determined, whereas for rat V2R, CRE-luc reporter activity was determined. Forty-eight hours after transfection, cells were treated with graded concentrations of $\mathrm{V} 1 \mathrm{a}$ antagonist $(\diamond)$, V2 antagonist $(\diamond)$, and OT antagonist $(\boldsymbol{\Delta})$ in the presence of $10 \mathrm{nM} \mathrm{VT,} \mathrm{MT,} \mathrm{AVP,} \mathrm{and} \mathrm{OT} \mathrm{for} \mathrm{VTR,} \mathrm{MTR,} \mathrm{rat} \mathrm{V1aR}$ and V2R, and human OTR respectively.

not show any hybridization signal (Fig. 7B, left hemisection).

\section{MTR mRNA}

In the telencephalon, a strong hybridization signal was observed in the ventral striatum (Fig. 8A), the dorsal lateral and medial pallium (Fig. 8A and B), and the lateral and medial amygdala (Fig. 8B and
G). A moderate MTR mRNA signal was seen in the lateral septum (Fig. 8A), the dorsal striatum (Fig. 8A), the nucleus accumbens (Fig. 8A), and the anterior commissure (Fig. 8B). A low density of MTR mRNA was detected in the internal granular layer of the olfactory bulb, the medial septum (Fig. 8A), the anterior entopeduncular nucleus (Fig. 8B), and the bed nucleus of the pallial commissure (Fig. 8B).

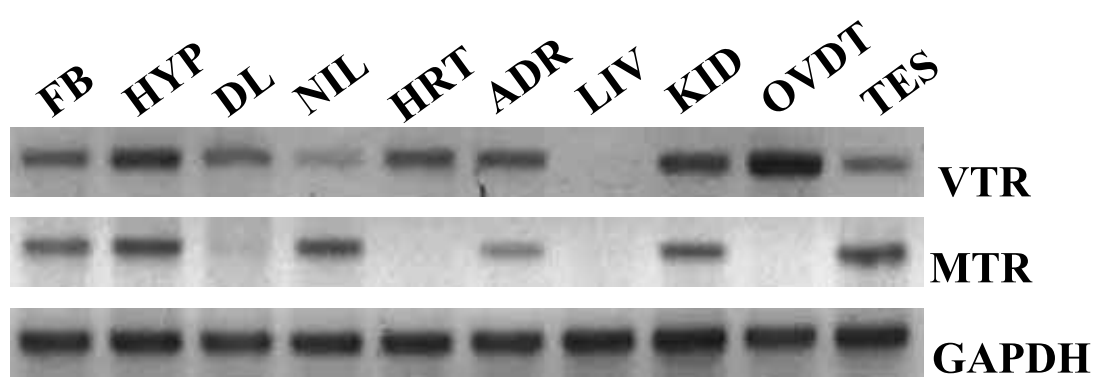

Figure 6 Tissue distribution of bullfrog VTR and MTR. RT-PCR was performed in different tissues, forebrain (FB), hypothalamus (HYP), distal lobe of the pituitary (DL), neurointermediate lobe of the pituitary (NIL), heart (HRT), adrenal gland (ADR), liver (LIV), kidney (KID), oviduct (OVDT), and testis (TES), with 30 rounds of amplification, to determine the distribution of VTR and MTR. RT-PCR amplification was performed in the same conditions with glyceraldehyde 3-phosphate dehydrogenase (GAPDH) primers. 
Table 4 Comparative distribution and relative abundance of VTR and MTR mRNAs, and VT- and MT-immunoreactive cell bodies and fibers in the brain and pituitary of the frog Rana esculenta

\section{Structures ${ }^{a}$}

Telencephalon

Anterior commissure $(A C)$

Anterior entopeduncular nucleus (Ea)

Bed nucleus of the pallial commissure (BN)

Dorsal pallium (DP)

Dorsal striatum (DS)

Lateral amygdala (LA)

Lateral pallium (LP)

Lateral septum (LS)

Medial amygdala (MA)

Medial pallium (MP)

Medial septum (MS)

Nucleus accumbens (NA)

Olfactory blub, extragranular plexiform layer (EPL)

Olfactory blub, glomerular layer (GL)

Olfactory bulb, internal granular layer (IGL)

Olfactory bulb, mitral cellular layer (ML)

Olfactory tubercle (TO)

Postolfactory eminence (PE)

Ventral striatum (VS)

\section{Diencephalon}

Anterior preoptic area (Poa)

Anterior thalamic nucleus $(A)$

Bed nucleus of the stria medullaris (BM)

Central thalamic nucleus (CNT)

Corpus geniculatum thalamicum (CP)

Dorsal hypothalamic nucleus $(\mathrm{DH})$

Dorsal habenular nucleus $(\mathrm{Hd})$

Epiphysis (E)

Lateral thalamic nucleus, anterior division (La)

Lateral hypothalamic nucleus (LH)

Lateral thalamic nucleus, posterodorsal division (Lpd)

Lateral thalamic nucleus, posteroventral division (Lpv)

Magnocellular preoptic nucleus $(\mathrm{Mg})$

Magnocellular preoptic nucleus, dorsal part (Mgd)

Magnocellular preoptic nucleus, ventral part (Mgv)

Neuropil of Bellonci (B)

Nucleus of Bellonci (NB)

Nucleus of the periventricular organ (NPv)

Optic chiasma (OC)

Optic nerve (ON)

Organum vasculosum (OV)

Posterior entopeduncular nucleus (Ep)

Posterior thalamic nucleus $(\mathrm{P})$

Posterior tuberculum (TP)

Subcommissural organ (CO)

Superficial ventral thalamic nucleus (Vs)

Suprachiasmatic nucleus (SC)

Thalamic eminence (TE)

Uncinate neuropil $(\mathrm{U})$
Accessory olfactory bulb (AOB)

\begin{tabular}{|c|c|c|c|c|c|}
\hline \multirow[b]{2}{*}{$\begin{array}{l}\text { VTR } \\
\text { mRNA }\end{array}$} & \multirow[b]{2}{*}{$\begin{array}{l}\text { MTR } \\
\text { mRNA }\end{array}$} & \multicolumn{2}{|l|}{ VTb } & \multicolumn{2}{|l|}{ MT'b } \\
\hline & & $\begin{array}{l}\text { Cell } \\
\text { bodies }\end{array}$ & Fibers & $\begin{array}{l}\text { Cell } \\
\text { bodies }\end{array}$ & Fibers \\
\hline
\end{tabular}

$\begin{array}{llllll}- & - & - & - & - & - \\ - & ++ & ++ & + & ++ & ++ \\ + & + & - & + & - & + \\ - & + & - & - & - & - \\ +++ & +++ & - & - & - & + \\ +++ & ++ & - & + & - & + \\ +++ & +++ & ++ & ++ & - & + \\ +++ & +++ & + & + & - & + \\ ++ & ++ & + & +++ & - & ++ \\ + & +++ & ++ & +++ & + & ++ \\ ++ & +++ & - & - & - & ++ \\ + & + & + & + & - & + \\ +++ & ++ & ++ & ++ & - & ++ \\ - & - & - & + & - & + \\ - & - & - & - & - & - \\ + & + & - & + & + & + \\ - & - & - & - & - & - \\ + & - & - & + & - & + \\ + & - & - & - & - & + \\ +++ & +++ & - & + & - & +\end{array}$

+
+
+
-
+
+
+
+
+
+
+
+
+
+
+
+
+
+
+

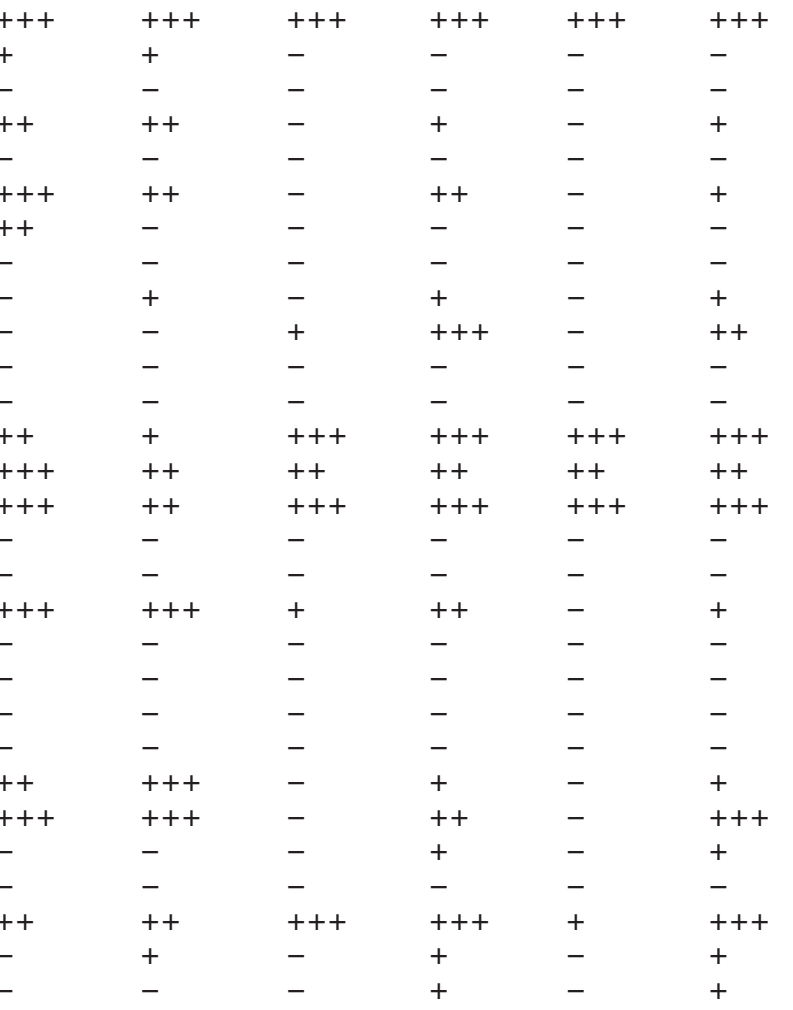




\begin{tabular}{|c|c|c|c|c|c|c|}
\hline & \multirow[b]{2}{*}{$\begin{array}{l}\text { VTR } \\
\text { mRNA }\end{array}$} & \multirow[b]{2}{*}{$\begin{array}{l}\text { MTR } \\
\text { mRNA }\end{array}$} & \multicolumn{2}{|l|}{$\mathbf{V T}^{\mathbf{b}}$} & \multicolumn{2}{|l|}{ MT'b } \\
\hline & & & $\begin{array}{l}\text { Cell } \\
\text { bodies }\end{array}$ & Fibers & $\begin{array}{l}\text { Cell } \\
\text { bodies }\end{array}$ & Fibers \\
\hline \multicolumn{7}{|l|}{ Structures $^{a}$} \\
\hline \multicolumn{7}{|l|}{ Diencephalon continued } \\
\hline Ventral habenular nucleus (Hv) & ++ & + & - & ++ & - & ++ \\
\hline Ventral hypothalamic nucleus (VH) & +++ & ++ & +++ & +++ & - & ++ \\
\hline Ventrolateral thalamic nucleus, dorsal part (VId) & + & + & - & - & - & - \\
\hline Ventrolateral thalamic nucleus, ventral part (VIV) & + & + & - & - & - & - \\
\hline Ventromedial thalamic nucleus (VM) & +++ & ++ & - & + & - & + \\
\hline \multicolumn{7}{|l|}{ Mesencephalon } \\
\hline Anterodorsal tegmental nucleus (AD) & ++ & ++ & - & + & - & + \\
\hline Anterioventral tegmental nucleus (AV) & ++ & ++ & + & ++ & - & ++ \\
\hline Basic optic nucleus (BON) & - & - & - & - & - & - \\
\hline Nucleus interpeduncularis (NIP) & _- & _ & _ & + & _- & ++ \\
\hline Nucleus lentiformis mesencephali (NLM) & - & - & - & - & - & - \\
\hline Nucleus of the medial longitudinal fasiculus (NMLF) & ++ & + & - & + & - & + \\
\hline Nucleus of the posterior commissure (NPC) & - & _- & _ & _ & _ & _ \\
\hline Nucleus profundus mesencephali (NPM) & - & - & - & - & - & - \\
\hline Nucleus reticularis isthmi (RIS) & - & - & - & + & - & ++ \\
\hline Oculomotor and trochlear nuclei (III) & - & - & - & + & - & + \\
\hline Optic tectum (OT) & +++ & +++ & - & ++ & - & ++ \\
\hline Pretectal gray $(\mathrm{PtG})$ & ++ & + & - & + & - & + \\
\hline Pretoral gray (PtrG) & +++ & ++ & - & + & - & + \\
\hline Tectal lamina six (6) & ++ & ++ & - & + & - & + \\
\hline Torus semicircularis (TS) & ++ & ++ & - & + & - & ++ \\
\hline \multicolumn{7}{|l|}{ Metencephalon } \\
\hline Auricular lobe of the cerebellum (CAL) & - & - & - & - & - & - \\
\hline Granular cell layer of the cerebellum (GC) & + & + & _- & + & - & + \\
\hline Molecular cell layer of the cerebellum (MC) & - & - & - & - & - & - \\
\hline Purkinje cell layer of the cerebellum (PC) & - & - & - & - & - & - \\
\hline \multicolumn{7}{|l|}{ Rhombencephalon } \\
\hline Choroid plexus (Pch) & - & - & - & - & - & _ \\
\hline Dorsal nucleus of the stato-acusticus nerve (VIII d) & - & - & - & - & - & - \\
\hline Fasciculus solitarius (FS) & - & _- & _- & - & - & _- \\
\hline Griseum centrale rhombencephali (Gc) & + & + & _- & + & _ & + \\
\hline Nucleus of the abducent nerve (VI) & + & + & - & + & - & + \\
\hline Nucleus of the facial nerve (VII) & + & + & _- & + & - & + \\
\hline Nucleus of the glossopharyngeal nerve (IX) & - & - & - & - & - & - \\
\hline Nucleus of the hypoglossal nerve (XII) & - & - & - & - & - & - \\
\hline Nucleus of the trigeminal nerve $(\mathrm{V})$ & _- & _ & _ & _- & - & _ \\
\hline Nucleus raphes (Ra) & - & - & - & - & - & - \\
\hline Nucleus reticularis inferior $(\mathrm{Ri})$ & - & - & - & + & - & + \\
\hline Nucleus reticularis medius (Rm) & - & - & - & + & - & + \\
\hline Sulcus limitans (SL) & - & - & - & - & - & - \\
\hline Ventral nucleus of the stato-acusticus nerve (VIII v) & + & + & - & + & - & + \\
\hline \multicolumn{7}{|l|}{ Pituitary } \\
\hline Pars distalis (Pdis) & ++ & ++ & - & - & - & - \\
\hline Pars intermedia $(\mathrm{PI})$ & ++ & ++ & - & ++ & - & ++ \\
\hline Pars nervosa (PN) & - & - & _- & ++ & _ & ++ \\
\hline
\end{tabular}

+++ , high density; ++, moderate density; +, low density; -, no mRNA hybridization signal, or immunoreactive cell bodies and fibers. Quantification of the optic density (OD) of the autoradiograms was performed by means of a computer-assisted image analyzer and the OD values were used to qualify the relative density of receptor mRNA: +++, OD $>50 ;++, 50>O D \geq 30 ;+, 30>0 D>10 ;-$, $\mathrm{OD} \leq 10$.

aAnatomical structures are designated according to Northcutt \& Kicliter (1980), Neary \& Northcutt (1983) and González et al. (1994). bThe distribution of VT- and MT-immunoreactive elements in the frog brain is from Lamacz et al. (1989), González \& Smeets (1992), Boyd et al. (1992) and Smeets \& González (2001). 


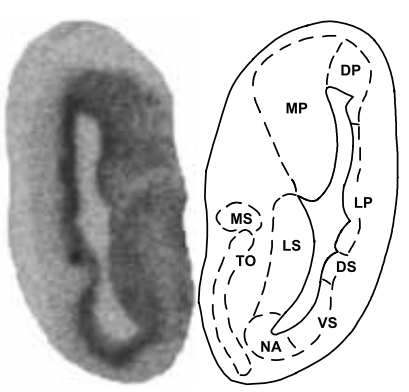

A
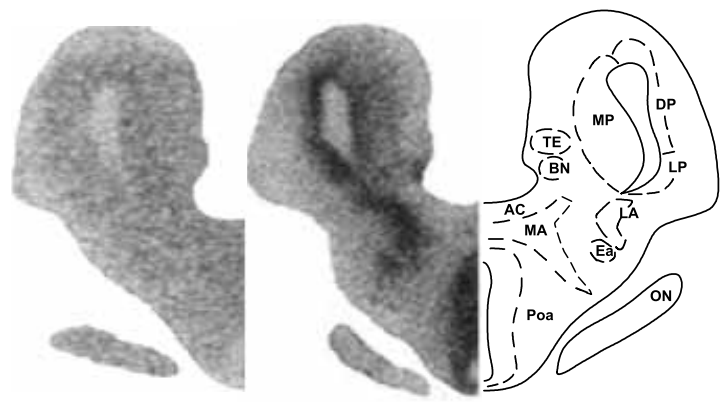

B

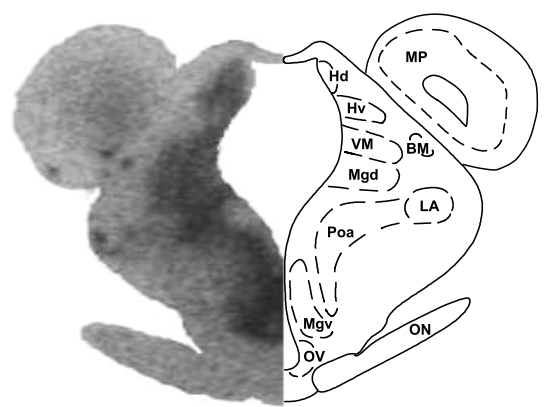

C

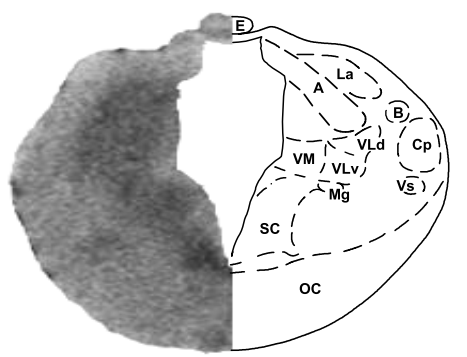

D

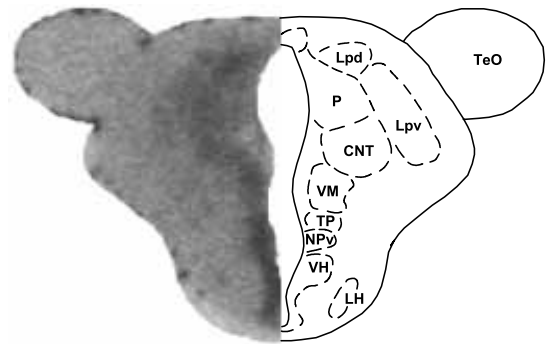

$\mathbf{E}$

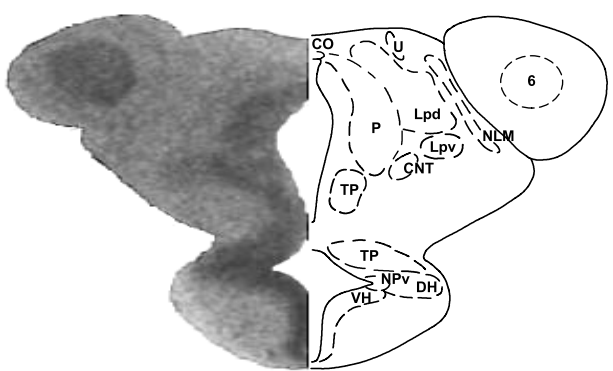

F

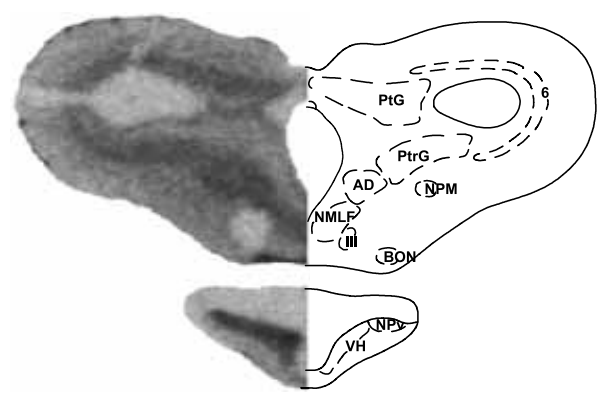

G

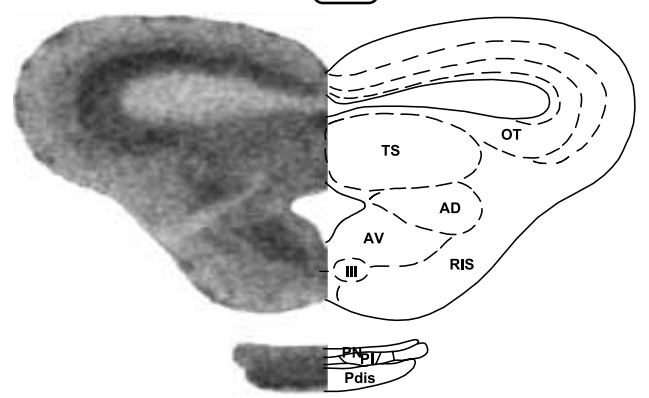

$\mathbf{H}$

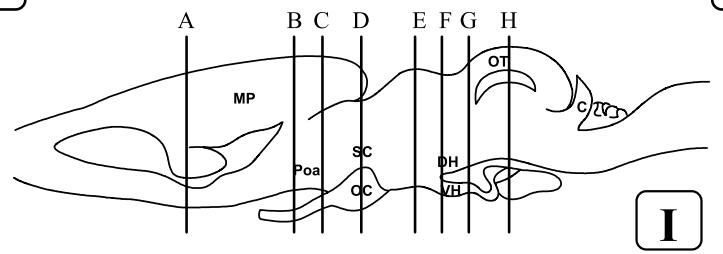


In the diencephalon, a high density of MTR mRNA was found in the anterior preoptic area (Fig. 8B), the nucleus of the periventricular organ (Fig. 8E), the posterior thalamic nucleus (Fig. 8E and F), and the posterior tuberculum (Fig. $8 \mathrm{E}$ and F). A moderate hybridization signal was visualized in the ventral aspect of the magnocellular preoptic nucleus (Fig. 8C), the suprachiasmatic nucleus (Fig. 8D), the ventromedial (Fig. 8C and D) and the central (Fig. 8E and F) thalamic nuclei, and the dorsal (Fig. 8F) and ventral (Fig. 8E-G) hypothalamic nuclei. A weak signal was detected in the thalamic eminence (Fig. 8B), the dorsal (Fig. 8C) and central (Fig. 8D) aspects of the magnocellular preoptic nucleus, the anterior division of the lateral hypothalamic nucleus (Fig. 8D), and the anterior thalamic nucleus (Fig. 8D).

In the mesencephalon, a strong MTR mRNA hybridization signal was observed in the optic tectum (Fig. 8H). Moderate labeling was visualized in tectal lamina six (Fig. 8F and G), the pretectal gray (Fig. 8G), and the anterodorsal and anteroventral tegmental nuclei (Fig. 8G and $\mathrm{H}$ ). Low MTR mRNA level was also detected in the nucleus of the medial longitudinal fasciculus (Fig. 7G), the pretectal gray (Fig. 8G), and the torus semicircularis (Fig. $8 \mathrm{H}$ ).

In the pituitary, a moderate concentration of MTR mRNA was seen in the distal and intermediate lobes but no hybridization signal was detected in the neural lobe (Fig. 8H).

Control sections treated with the sense MTR probe exhibited only background labeling (Fig. 8F, left hemisection).

\section{Discussion}

The bullfrog $R$. catesbeiana and the European green frog $R$. esculenta have long been used as models for studying the neuroendocrine and behavioral activities of the neurohypophysial hormones VT and MT (Warburg 1995, Boyd 1997). However, none of the receptors mediating the effects of VT and MT in these two advantageous amphibian species models has yet been characterized. Here, we report the molecular cloning of a Vla-like VTR and the MTR in both $R$. catesbeiana and $R$. esculenta. We have also investigated the pharmacological profile of these two receptors and compared their ligand selectivity to those of their mammalian counterparts, and we have determined the distribution of the mRNAs encoding VTR and MTR in the frog brain and pituitary.

The cloned frog VTR and MTR, like their mammalian counterparts, belong to the rhodopsin family of GPCRs as they exhibit the typical Asp residue at $2 \cdot 50$ position of transmembrane domain II (TMDII) (at amino acid position 105 in VTR and 85 in MTR) and an NPXXY motif in TMDVII (Bockaert \& Pin 1999). The frog VTR and MTR also possess several amino acid sequences that are highly conserved in neurohypophysial hormone receptors, such as an FQVLPQ motif in TMDII, a Gln residue in TMDII (at position 139 for VTR and 119 for MTR), and Gln and Phe residues in TMDIV (positions 171 and 197 for VTR, and 193 and 175 for MTR respectively). Mutational analyses of neurohypophysial hormone receptors have previously shown that these conserved residues are important for ligand binding (Mouillac et al. 1995, Hausmann et al. 1996).

Frog VTR and MTR exhibited differential ligand sensitivity and signaling pathway from each other, but possessed functional similarity to their mammalian counterparts, i.e. AVP and OT receptors respectively. Upon ligand stimulation, frog VTR, and mammalian V1aR and V2R activated both CRE- and c-fos-promoter-driven transcriptional activity. For VTR and VlaR, c-fos-promoter-driven transcriptional activity was higher than GRE-driven transcriptional activity while for V2R, CRE-driven transcriptional activity was slightly higher than c-fos-promoter-driven transcriptional activity. It is known that the V2R primarily couples to Gs (Liu \& Wess 1996) while

Figure 7 In situ hybridization analysis showing the distribution of VTR mRNA in the brain and pituitary of Rana esculenta. (A-H) Frontal brain sections were hybridized with a ${ }^{35}$ S-labeled Rana esculenta VTR riboprobe and exposed onto Hyperfilm $\beta$-max for 2 weeks. A control section treated with the sense ${ }^{35}$ S-labeled VTR riboprobe (B, left hemisection) is compared with a consecutive section hybridized with the antisense probe ( $\mathrm{B}$, middle hemisection). The anatomical structures, identified by microscopic analysis, are designated on the right hemisections according to Neary \& Northcutt (1983). (I) The rostrocaudal levels of the sections are indicated on the schematic sagittal section. For abbreviations, see Table 4. 


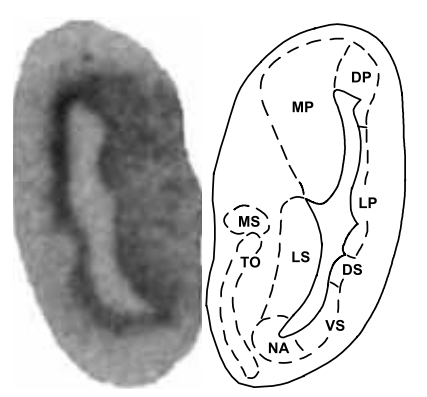

A

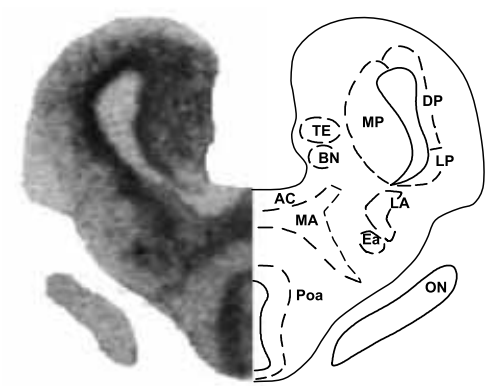

B
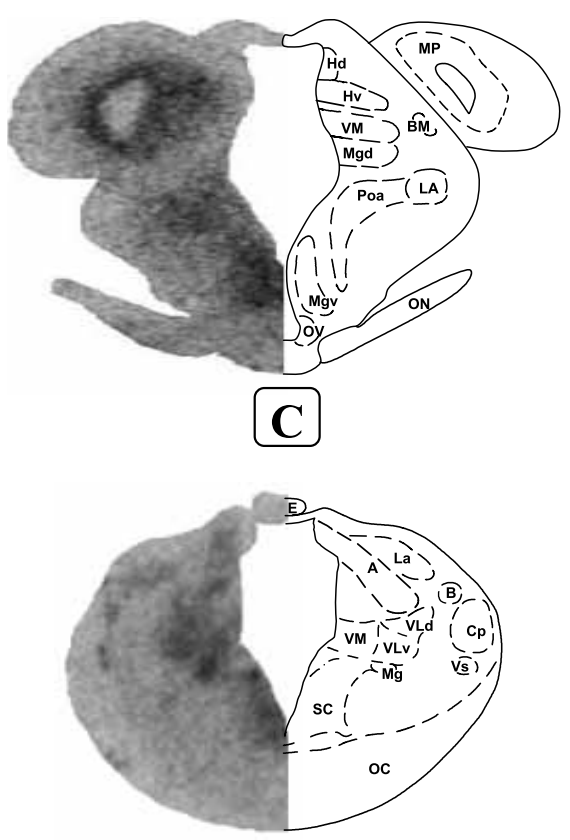

D

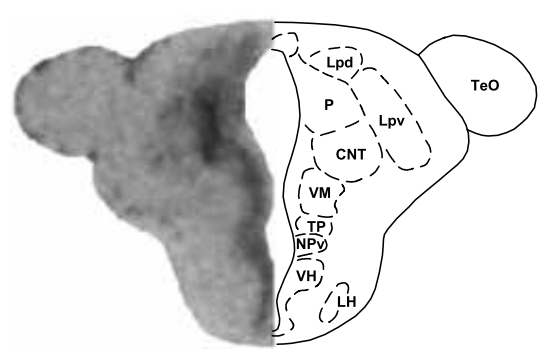

E
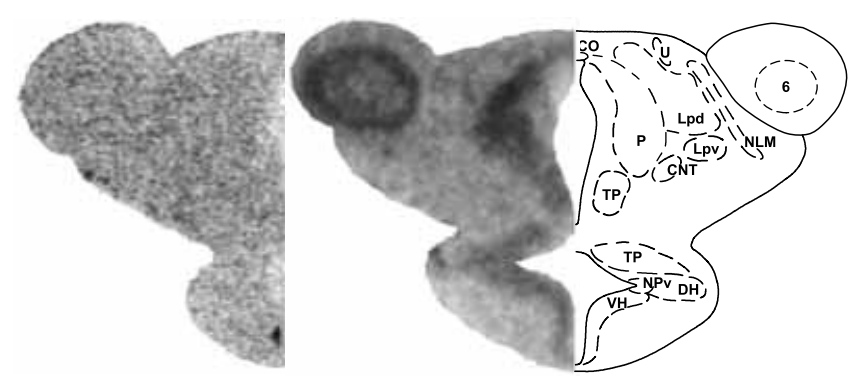

F
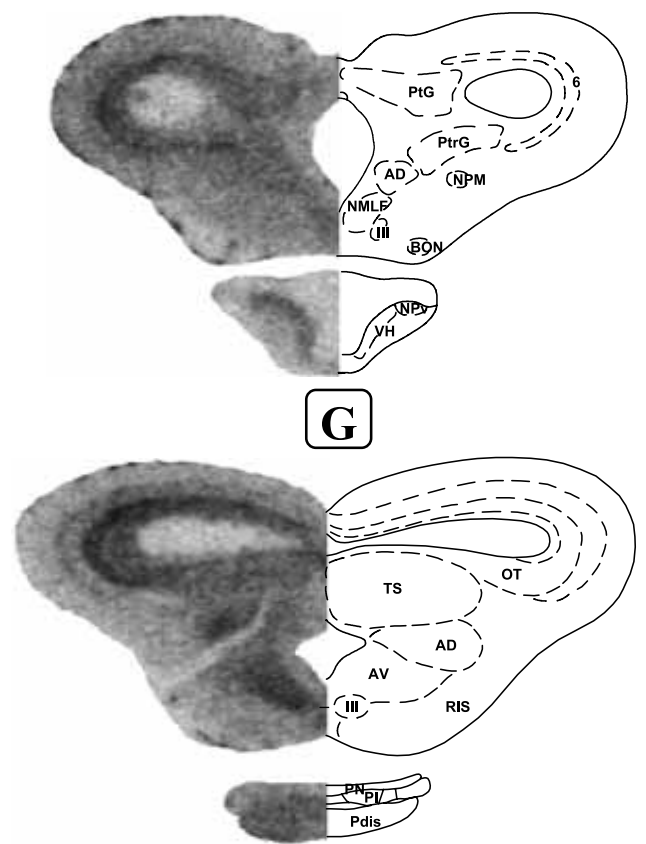

H

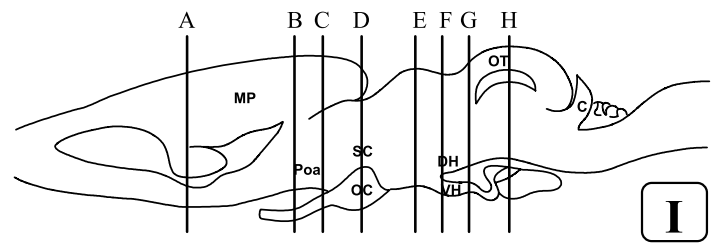


our study showed that the rat V2R could activate both the CRE- and c-fos-luc activity. Our findings can be supported by a previous report showing that overexpression (100 000 sites/cell) of the V2R can stimulate phospholipase $\mathrm{C}$, which explains the dual signaling potential of the V2R (Zhu et al. 1994). Alternatively, the reporter system used in this study is more sensitive than the second messenger assay system which allows us to detect amplified signals through multiple signaling cascades. These observations indicated that $\mathrm{AVP} / \mathrm{VT}$ receptors couple to both PKA- and PKC-mediated signaling pathways, but that VTR and VlaR preferentially couple to PKC-linked signaling, while V2R preferentially couple to PKA-linked signaling, which is in good agreement with previous reports (Liu \& Wess 1996). Concurrently, frog MTR and OTR triggered only c-fos-promoter-driven transcriptional activity, indicating that MTR and OTR exclusively couple to the PKC-mediated signaling pathway. We found that VTR, like VlaR, contains a highly conserved triplet of residues (Asp-Arg-Tyr, DRY) at the boundary between TMDIII and intracellular loop 2 (ICL2), which is a common feature of the rhodopsin family of GPCRs (Bockaert \& Pin 1999). Interestingly, in MTR, the DRY motif was changed to DRC as found in the OTR (Gimpl \& Fahrenholz 2001), while this motif is modified to DRH in V2R (Lolait et al. 1992). The DRY motif plays a pivotal role in $G$ protein coupling and is important for receptor activation and internalization (Arora et al. 1997, Gether \& Kobilka 1998, Mitchell et al. 1998). Substitution of the Tyr residue in the DRY motif may thus account for the differential signaling between VT/AVP receptors and MT/OT receptors. Alternatively, differential signaling may be ascribed to amino acid substitutions in ICLs. It has been demonstrated that chimeric receptors having the VlaR sequence in ICL2 are able to activate the phosphatidylinositol pathway with high efficiency, while hybrid receptors containing the V2R sequence in ICL3 are capable of efficiently stimulating cAMP production (Liu \& Wess 1996). Another motif at the junction between TMDV and ICL3, GYGLISF/YKIW, is highly conserved in MTR and OTR, but not in VTR/VlaR and in V2R. The lack of conservation of this motif may also explain the differential signal transduction activated by VT/AVP receptors and $\mathrm{MT} / \mathrm{OT}$ receptors. Recently, VTR and MTR have been cloned from the Japanese treefrog Hyla japonica (Kohno et al. 2003). This VTR differs considerably from the bullfrog VTR. The Japanese treefrog VTR shows high homology with the mammalian V2R subtype and couples to Gs. So, it is likely that the amphibians possess two different kinds of VTR, one resembling the mammalian Vla subtype and the other representing the mammalian V2 subtype.

With regard to ligand sensitivity, the VT/AVP receptor family responded better to VT than MT, while MT/OT receptors were more sensitive to MT than VT. This finding indicated that the specific amino acids responsible for ligand selectivity are conserved within the VT/AVP and $\mathrm{MT} / \mathrm{OT}$ receptor families. It is known that the $\mathrm{Tyr}^{115}$ residue in extracellular loop 1 (ECL1) of the human VlaR is crucial for agonist selectivity (Chini et al. 1995). Interestingly, this residue is substituted to Asp in the V2R and to Phe in the OTR respectively. It has been suggested that amino acid at position 8 (Arg for VT/AVP and Leu for $\mathrm{MT} / \mathrm{OT}$ ) in neurohypophysial nonapeptides may interact with the amino acid at this position $\left(\mathrm{Tyr}^{115}\right.$ for V1aR, Asp ${ }^{103}$ for V2R, and $\mathrm{Phe}^{103}$ for OTR). $\mathrm{AVP}$ and VT that possess an $\mathrm{Arg}^{8}$ residue exhibit similar sensitivity to V1aR, V2R and OTR, whereas OT and AVP with an $\mathrm{Arg}^{8} \rightarrow$ Leu substitution exhibit highest sensitivity to OTR and a remarkable decrease in sensitivity to $\mathrm{VlaR}$ and V2R (Chini et al. 1995). Like VlaR, frog VTR contains a Tyr residue at this position, while frog MTR has a Phe residue as has the OTR. These observations suggest that a single amino acid

\footnotetext{
Figure 8 In situ hybridization analysis showing the distribution of MTR mRNA in the brain and pituitary of Rana esculenta. (A-H) Frontal brain sections were hybridized with a ${ }^{35}$ S-labeled Rana esculenta MTR riboprobe and exposed onto Hyperfilm $\beta$-max for 2 weeks. A control section treated with the sense ${ }^{35}$ S-labeled MTR riboprobe $(F$, left hemisection) is compared with a consecutive section hybridized with the antisense probe ( $F$, central hemisection). The anatomical structures, identified by microscopic analysis, are designated on the right hemisections according to Neary \& Northcutt (1983). (I) The rostrocaudal levels of the sections are indicated on the schematic sagittal section. For abbreviations, see Table 4.
} 
difference at this position may confer differential ligand selectivity between the VT/AVP and MT/OT receptor families. It thus appears that a high selective pressure has acted to conserve crucial amino acid residues that confer selectivity of each receptor subfamily for its natural ligand. Surprisingly however, AVP, the mammalian counterpart of VT, was a very poor agonist of VTR. In fact, frog VTR exhibited the same rank order of potency (VT>OT $>$ AVP $\approx \mathrm{MT}$ ) as a fish VTR (Mahlmann et al. 1994), whereas chicken VT1R exhibited a different order of potency, AVT $\approx$ $\mathrm{AVP}>\mathrm{OT} \approx \mathrm{MT}$ (Tan et al. 2000) so that the VTR of lower vertebrates exhibits low affinity for AVP while the VTR of higher vertebrates has high sensitivity to AVP. These observations imply that, during the process of co-evolution of neurohypophysial nonapeptides and their receptors, changes of VT/AVP receptors preceded those of their ligands.

Agonists and antagonists for V1a, V2, and OT that are highly selective for the respective mammalian receptors did not discriminate frog VTR and MTR. In particular, the Vla agonist $\left[\mathrm{Phe}^{2}, \mathrm{Orn}^{8}\right] \mathrm{OT}$ activated VTR and MTR with similar potency while V2 and OT agonists were totally devoid of activity on VTR and MTR. Site-directed mutagenesis studies combined with computer modeling indicate that the Asp ${ }^{97}, \mathrm{Gln}^{104}$, Gln ${ }^{108}, \operatorname{Lys}^{128}, \mathrm{Gln}^{131}, \mathrm{Gln}^{185}$, and Gln ${ }^{311}$ residues of the human VlaR interact with AVP and the Vla agonist (Mouillac et al. 1995). Interestingly, these amino acids are well conserved in frog VTR and MTR. It has previously been shown that AVP and Vla agonist have poor selectivity for $\mathrm{Vla}$ and $\mathrm{V} 2 \mathrm{R}$, while the $\mathrm{V} 2$ agonist [deamino- $\mathrm{Cys}{ }^{1}, \mathrm{Val}^{4}, \mathrm{D}-$ $\mathrm{Arg}^{8}$ ]AVP exhibits high specificity for V2R having Asp at position 103 (Chini et al. 1995, Ufer et al. 1995). The fact that the amino acid residues at this position in VTR and MTR are Tyr and Phe respectively may account for the failure of the $\mathrm{V} 2$ agonist to activate frog VTR and MTR. It is also interesting to note that none of the $\mathrm{Vla}, \mathrm{V} 2$ and OT antagonists inhibited VT-induced VTR activation, while these antagonists inhibited MTinduced MTR activation to some extent. It has been previously shown that mutations in agonistbinding sites of $\mathrm{VlaR}$ do not affect antagonist binding, indicating that the residues responsible for agonist and antagonist binding to $\mathrm{VlaR}$ are different (Mouillac et al. 1995). It is known that aromatic residues in TMDVI of human VlaR $\left(\operatorname{Trp}^{304}, \mathrm{Phe}^{307}\right.$, and $\mathrm{Phe}^{308}$ ) are responsible for Vla antagonist binding (Cotte et al. 2000). The corresponding residues in both VTR and MTR are well conserved except for Phe ${ }^{307}$. In VTR, Phe ${ }^{307}$ is replaced by Tyr, suggesting that this substitution may account for the insensitivity of the nonapeptide antagonist towards VTR even though VTR and VlaR show a high degree of sequence identity. Another motif in TMDIII (Leu-Val-Lys, LVK for OTR and Val-Val-Lys, VVK for VlaR) has recently been found to be responsible for binding cyclic peptide antagonist (Breton et al. 2001). Like OTR, frog MTR contains an LVK motif, whereas VTR has an Ile-Ile-Lys (IIK) motif instead of the VVK sequence found in VlaR, suggesting that the failure of the nonapeptide antagonists to inhibit VT-induced VTR activation may be ascribed to the VVK $\rightarrow$ IIK double substitution. These results indicate that although frog VTR and MTR exhibit high selectivity for natural ligands they show poor selectivity for the agonist and antagonist. It appears therefore that a degree of caution should be taken when using the agonists and antagonists designed for mammalian AVP and OT receptors to characterize the pharmacological profile of amphibian VTR and MTR.

RT-PCR analysis and in situ hybridization histochemistry revealed that the mRNAs encoding frog Vla-type VTR and MTR were differentially expressed although they largely overlapped in many regions of the brain and peripheral organs. The occurrence of VTR mRNA in the distal lobe of the pituitary is consistent with a role of VT in the control of ACTH secretion (Tonon et al. 1986). Previous studies have shown that the intermediate lobe of the pituitary is innervated by MTcontaining fibers (Dierickx \& Vandesande 1976, Tonon et al. 1985, Lamacz et al. 1989). The fact that MTR mRNA is actively expressed in the pars intermedia strongly suggests that MT controls the activity of pituitary melanotrophs. The intense expression of VTR mRNA in the frog adrenal gland is in agreement with functional studies that have shown that AVP is a potent stimulator of corticosterone and aldosterone secretion in vitro (Larcher et al. 1989, 1992a). Interestingly, the rank order of potency of the natural nonapeptides on recombinant VTR (VT>OT $>\mathrm{AVP} \approx \mathrm{MT}$ ) was similar to that observed on frog adrenocortical cells (Larcher et al. 1992a). 
In the brain, the distribution of VTR and MTR largely overlapped in the telencephalon, diencephalon, and mesencephalon (Table 4). In a few regions, however, one of the receptors was more intensely expressed than the other. For example, in the medial amygdala, MTR mRNA was far more abundant than VTR mRNA whereas in the dorsal aspect of the magnocellular preoptic nucleus, VTR mRNA was predominant.

A strong correlation was observed between the localization of VT- and MT-immunoreactive fibers and the distribution of VTR and MTR mRNAs respectively (Table 4). For instance, several areas such as the lateral septum, the accumbens nucleus, the anterior preoptic area, the dorsal hypothalamic nucleus, the ventral part of the magnocellular preoptic nucleus, and the ventral hypothalamic nucleus contained high density of VT fibers and a dense accumulation of VTR mRNA. In amphibians, VT administration enhances reproductive behavior, i.e. vocalization, male amplectic clasping behavior, and female sexual receptivity (Moore 1992, Boyd 1997). In this respect, the dense network of VT-containing fibers and the intense expression of VTR mRNA in the anterior preoptic area is of particular interest since this nucleus is clearly involved in the regulation of male calling behavior (Boyd 1997) and sexual activity (Moore et al. 2000).

However, in a few regions of the brain, mismatching was observed between the localization of VT- or MT-immunoreactive fibers and VTR or MTR mRNAs respectively (Table 4). For example, the dorsal pallium, the ventral striatum, and the nucleus of the periventricular organ exhibited intense MTR mRNA expression but contained very few MT-positive processes. The receptors expressed in these areas may be influenced by nonapeptides released at a distance, i.e. through volume transmission (Fuxe \& Agnati 1991, MacMillan et al. 1998). Reciprocally, the lateral hypothalamic nucleus that is innervated by a high density of VT fibers did not express VTR mRNA, suggesting that these VT-positive processes project towards distant areas.

In conclusion, we have cloned and functionally characterized two different neurohypophysial peptide receptors in the frog. Although the distribution of VTR and MTR mRNAs overlapped in many brain regions and in some peripheral tissues, these receptors may play distinct roles as they showed differential ligand sensitivity and signal transduction mechanisms. This study will provide important information for the development of new analogs for VT/AVP and MT/OT families.

\section{Acknowledgements}

This work was supported in part by grants from the Korea Research Foundation Grant (KRF-2002070-C007), the Korea Science and Engineering Foundation (KOSEF) through the Hormone Research Center (HRC-2002-G0102), INSERM (U413) and a STAR exchange program to H B K, J Y S and H V. D Y O was supported by a Brain Korea 21 research fellowship from the Korea Ministry of Education.

\section{Footnote}

The sequences reported in this paper have been deposited in the GenBank data base (accession nos. AY277924 for bullfrog VTR and AY277925 for bullfrog MTR).

\section{References}

Acher R, Chauvet J \& Chauvet MT 1995 Man and the chimaera. Selective versus neutral oxytocin evolution. Advances in Experimental Medicine and Biology 395 615-627.

Akhundova A, Getmanova E, Gorbulev V, Carnazi E, Eggena P \& Fahrenholz F 1996 Cloning and functional characterization of the amphibian mesotocin receptor, a member of the oxytocin/ vasopressin receptor superfamily. European Fournal of Biochemistry 237 759-767.

Alescio-Lautier B \& Soumireu-Mourat B 1998 Role of vasopressin in learning and memory in the hippocampus. Progress in Brain Research 119 501-502.

Alexandre D, Anouar Y, Jegou S, Fournier A \& Vaudry H 1999 A cloned frog vasoactive intestinal polypeptide/pituitary adenylate cyclase-activating polypeptide receptor exhibits pharmacological and tissue distribution characteristics of both VPAC1 and VPAC2 receptors in mammals. Endocrinology 140 1285-1293.

Arora KK, Cheng Z \& Catt KJ 1997 Mutations of the conserved DRS motif in the second intracellular loop of the gonadotropinreleasing hormone receptor affect expression, activation, and internalization. Molecular Endocrinology 11 1203-1212.

Barberis C, Mouillac B \& and Durroux T 1998 Structural bases of vasopressin/oxytocin receptor function. Fournal of Endocrinology 156 223-229.

Bockaert J \& Pin JP 1999 Molecular tinkering of G protein-coupled receptors: an evolutionary success. EMBO fournal 18 1723-1729.

Boyd SK 1997 Brain vasotocin pathways and the control of sexual behaviors in the bullfrog. Brain Research Bulletin 44 345-350.

Boyd SK, Tyler CJ \& De Vries GJ 1992 Sexual dimorphism in the vasotocin system of the bullfrog (Rana catesbeiana). Fournal of Comparative Neurology 325 313-325. 
Breton C, Chellil H, Kabbaj-Benmansour M, Carnazzi E, Seyer R, Phalipou S, Morin D, Durroux T, Zingg H, Barberis C \& Mouillac B 2001 Direct identification of human oxytocin receptor-binding domains using a photoactivatable cyclic peptide antagonist: comparison with the human $\mathrm{Vla}$ vasopressin receptor. Fournal of Biological Chemistry 276 26931-26941.

Burbach JPH, Adan RAH, Lolait SJ, van Leeuwen FW, Mezey E, Palkovits M \& Barberis C 1995 Molecular neurobiology and pharmacology of vasopressin/oxytocin receptor family. Cellular and Molecular Neurobiology 15 573-595.

Chibbar R, Miller FD \& Mitchell BF 1993 Synthesis of oxytocin in amnion, chorion, and decidua may influence the timing of human parturition. Fournal of Clinical Investigation 91 185-192.

Chini B, Mouillac B, Ala Y, Balestre MN, Trumpp-Kallmeyer S, Hoflack J, Elands J, Hibert M, Manning M, Jard S \& Barberis C 1995 Tyrl15 is the key residue for determining agonist selectivity in the Vla vasopressin receptor. EMBO Fournal 14 2176-2182.

Cotte N, Balestre MN, Aumelas A, Mahe E, Phalipou S, Morin D, Hibert M, Manning M, Durroux T, Barberis C \& Mouillac B 2000 Conserved aromatic residues in the transmembrane region VI of the Vla vasopressin receptor differentiate agonist vs. antagonist ligand binding. European Fournal of Biochemistry 267 4253-4263.

De Rouffignac C, Di Stefano A, Wittner M, Roinel N \& Elalouf JM 1991 Consequences of differential effects of ADH and other peptide hormones on thick ascending limb of mammalian kidney. American Fournal of Physiology 260 R1023-R1035.

Dierickx K \& Vandesande F 1976 Immuno-enzyme cytochemical demonstration of mesotocinergic nerve fibers in the pars intermedia of the amphibian hypophysis. Cell and Tissue Research $17425-53$.

Fuxe K \& Agnati LF 1991 Volume transmission in the brain. Novel mechanisms for neuronal transmission. In Advances in Neurosciences, pp 1-9. Eds K Fuxe \& LF Agnati New York: Raven Press.

Gether U \& Kobilka BK 1998 G protein-coupled receptors. II. Mechanism of agonist activation. Foumal of Biological Chemistry 273 17979-17982.

Gimpl G \& Fahrenholz F 2001 The oxytocin receptor system: structure, function, and regulation. Physiological Reviews $\mathbf{8 1}$ 629-683.

González A \& Smeets WJAJ 1992 Comparative analysis of the vasotocinergic and mesotocinergic cells and fibers in the brain of two amphibians, the anuran Rana ridibunda and the urodele Pleurodeles waltii. Fournal of Comparative Neurology 315 53-73.

González A, Marin O, Tuinhof R \& Smeets WJ 1994 Ontogeny of catecholamine systems in the central nervous system of anuran amphibians: an immunohistochemical study with antibodies against tyrosine hydroxylase and dopamine. Fournal of Comparative Neurology 346 63-79.

Hausmann H, Richters A, Kreienkamp HJ, Meyerhof W, Mattes H, Lederis K, Zwiers H \& Richter D 1996 Mutational analysis and molecular modeling of the nonapeptide hormone binding domains of the [Arg8]vasotocin receptor. PNAS 93 6907-6912.

Ivell R, Balvers M, Rust W, Bathgate R \& Einspanier A 1997 Oxytocin and male reproductive function. Advances in Experimental Medicine and Biology 424 253-264.

de Keyzer Y, Lenne F, Auzan C, Jegou S, Rene P, Vaudry H, Kuhn JM, Luton JP, Clauser E \& Bertagna X 1996 The pituitary $\mathrm{V} 3$ vasopressin receptor and the corticotroph phenotype in ectopic ACTH syndrome. Fournal of Clinical Investigation 97 $1311-1318$

Kimura T, Tanizawa O, Mori K, Brownstein MJ \& Okayama H 1992 Structure and expression of a human oxytocin receptor. Nature 356 526-529.

Kohno S, Kamishima Y \& Iguchi T 2003 Molecular cloning of an anuran $\mathrm{V}(2)$ type $[\operatorname{Arg}(8)]$ vasotocin receptor and mesotocin receptor: functional characterization and tissue expression in the
Japanese tree frog (Hyla japonica). General and Comparative Endocrinology 132 485-498.

Lamacz M, Hindelang C, Tonon MC, Vaudry H \& Stoeckel ME 1989 Three distinct thyrotropin-releasing hormoneimmunoreactive axonal systems project in the median eminence-pituitary complex of the frog Rana ridibunda. Immunocytochemical evidence for co-localization of thyrotropin-releasing hormone and mesotocin in fibers innervating pars intermedia cells. Neuroscience 32 451-462.

Larcher A, Delarue C, Idres S, Lefebvre H, Feuilloley M, Vandesande F, Pelletier G \& Vaudry H 1989 Identification of VT-like immunoreactivity in chromaffin cells of the frog adrenal gland: effect of VT on corticosteroid secretion. Endocrinology 125 2691-2700.

Larcher A, Delarue C, Homo-Delarche F, Kikuyama S, Kupryszewski G \& Vaudry H 1992a Pharmacological characterization of VT stimulation of phosphoinositide turnover in frog adrenal gland. Endocrinology 130 475-483.

Larcher A, Lamacz M, Delarue C \& Vaudry H $1992 b$ Effect of vasotocin on cytosolic free calcium concentrations in frog adrenocortical cells in primary culture. Endocrinology 131 1087-1093.

Liu J \& Wess J 1996 Different single receptor domains determine the distinct $\mathrm{G}$ protein coupling profiles of members of the vasopressin receptor family. Fournal of Biological Chemistry $2718772-8778$.

Lolait SJ, O'Carroll AM, McBride OW, Konig M, Morel A \& Brownstein MJ 1992 Cloning and characterization of a vasopressin V2 receptor and possible link to nephrogenic diabetes insipidus. Nature 357 336-339.

MacMillan MA, Mark MA \& Duan AW 1998 The release of $\beta$-endorphin and the neuropeptide-receptor mismatch in the brain. Brain Research 794 127-136.

Mahlmann S, Meyerhof W, Hausmann H, Heierhorst J, Schonrock C, Zwiers H, Lederis K \& Richter D 1994 Structure, function, and phylogeny of [Arg8]VT receptors from teleost fish and toad. PNAS 91 1342-1345.

Mitchell R, McCulloch D, Lutz E, Johnson M, MacKenzie C, Fennell M, Fink G, Zhou W \& Sealfon SC 1998 Rhodopsin-family receptors associate with small $\mathrm{G}$ proteins to activate phospholipase D. Nature 392 411-414.

Moore FL 1992 Evolutionary precedents for behavioral actions of oxytocin and vasopressin. Annals of the New York Academy of Sciences $652156-165$.

Moore FL, Richardson C \& Lowry CA 2000 Sexual dimorphism in numbers of vasotocin-immunoreactive neurons in brain areas associated with reproductive behaviors in the roughskin newt. General and Comparative Endocrinology 117 281-298.

Morel A, O'Carroll AM, Brownstein MJ \& Lolait SJ 1992 Molecular cloning and expression of a rat $\mathrm{Vla}$ arginine vasopressin receptor. Nature 356 523-526.

Mouillac B, Chini B, Balestre MN, Elands J, Trumpp-Kallmeyer S, Hoflack J, Hibert M, Jard S \& Barberis C 1995 The binding site of neuropeptide vasopressin Vla receptor. Evidence for a major localization within transmembrane regions. Fournal of Biological Chemistry $27025771-25777$.

Neary TJ \& Northcutt RG 1983 Nuclear organization of the bullfrog diencephalon. Fournal of Comparative Neurology 213 262-278.

Nishimori K, Young LJ, Guo Q, Wang Z, Insel TR \& Matzuk MM 1996 Oxytocin is required for nursing but is not essential for parturition or reproductive behavior. PNAS 93 11699-11704.

Northcutt RG \& Kicliter E 1980 Organization of the amphibian telencephalon. In Comparative Neurology of the Telencephalon, pp 203-255. Ed. SOE Ebbeson. New York: Plenum Press.

Oh da Y, Wang L, Ahn RS, Park JY, Seong JY \& Kwon HB 2003 Differential $G$ protein coupling preference of mammalian and nonmammalian gonadotropin-releasing hormone receptors. Molecular and Cellular Endocrinology 205 89-98. 
Pang PK \& Sawyer WH 1978 Renal and vascular responses of the bullfrog (Rana catesbeiana) to mesotocin. American Foumal of Physiology 235 F151-F155.

Pedersen CA \& Prange AJ Jr 1979 Induction of maternal behavior in virgin rats after intracerebroventricular administration of oxytocin. PNAS 76 6661-6665.

Rose JD \& Moore FL 2002 Behavioral neuroendocrinology of vasotocin and vasopressin and the sensorimotor processing hypothesis. Frontiers in Neuroendocrinology 23 317-341.

Seong JY, Wang L, Oh DY, Yun O, Maiti K, Li JH, Soh JM, Choi HS, Kim K, Vaudry H \& Kwon HB 2003 Ala/Thr(201) in extracellular loop 2 and Leu/Phe(290) in transmembrane domain 6 of type 1 frog gonadotropin-releasing hormone receptor confer differential ligand sensitivity and signal transduction. Endocrinology 144454466.

Sugimoto T, Saito M, Mochizuki S, Watanabe Y, Hashimoto S \& Kawashima H 1994 Molecular cloning and functional expression of a cDNA encoding the human V1b vasopressin receptor. Fournal of Biological Chemistry $26927088-27092$.

Szczepanska-Sadowska E 1996 Interaction of vasopressin and angiotensin II in central control of blood pressure and thirst. Regulatory Peptides 66 65-71.

Tan FL, Lolait SJ, Brownstein MJ, Saito N, MacLeod V, Baeyens DA, Mayeux PR, Jones SM \& Cornett LE 2000 Molecular cloning and functional characterization of a VT receptor subtype that is expressed in the shell gland and brain of the domestic chicken. Biology of Reproduction 62 8-15.

Tonon MC, Burlet A, Lauber M, Cuet P, Jegou S, Gouteux L, Ling N \& Vaudry H 1985 Immunohistochemical localization and radioimmunoassay of corticotropin-releasing factor in the forebrain and hypophysis of the frog Rana ridibunda.

Neuroendocrinology 40 109-1 19.

Tonon MC, Cuet P, Lamacz M, Jegou S, Cote J, Gouteux L, Ling N, Pelletier G \& Vaudry H 1986 Comparative effects of corticotropin-releasing factor, arginine vasopressin, and related neuropeptides on the secretion of ACTH and alpha-MSH by frog anterior pituitary cells and neurointermediate lobes in vitro. General and Comparative Endocrinology 61 438-445.

Ufer E, Postina R, Gorbulev V \& Fahrenholz F 1995 An extracellular residue determines the agonist specificity of V2 vasopressin receptors. FEBS Letters 362 19-23.

Warburg MR 1995 Hormonal effect on the osmotic, electrolyte and nitrogen balance in terrestrial amphibia. Zoological Science $121-11$.

Warne JM 2001 Cloning and characterization of an arginine VT receptor from the euryhaline flounder Platichthys flesus. General and Comparative Endocrinology 122 312-319.

de Wied D, Diamant M \& Fodor M 1993 Central nervous system effects of the neurohypophyseal hormones and related peptides. Frontiers in Neuroendocrinology 14 251-302.

Zhu X, Gilbert S, Birnbaumer M \& Birnbaumer L 1994 Dual signaling potential is common among Gs-coupled receptors and dependent on receptor density. Molecular Pharmacology 46 460-469.

Received 19 January 2004

Accepted 1 June 2004

Made available online as an Accepted Preprint 